\title{
IMPACTOS DA LIQUIDAÇÃO FINANCEIRA SOBRE A EFICIÊNCIA DE HEDGING NOS CONTRATOS FUTUROS DAS COMMODITIES BOI GORDO E SOJA
}

\section{LUIZ GONZAGA DE CASTRO JUNIOR}

Administrador Rural

Orientador: Prof. Dr. PEDRO VALENTIM MARQUES

Tese apresentada à Escola Superior de Agricultura "Luiz de Queiroz", Universidade de São Paulo, para obtenção do título de Doutor em Ciências, Área de Concentração: Economia Aplicada.

PIRACICABA

Estado de São Paulo - Brasil

Dezembro - 1998 
Dados Internacionais de Catalogação na Publicação (CIP) DIVISĀO DE BIBLIOTECA E DOCUMENTAÇĀO - Campus "Luiz de Queiroz"/USP

\section{Castro Junior, Luiz Gonzaga de}

Impactos da liquidação financeira sobre a eficiência de hedging nos contratos

futuros das commodities boi gordo e soja / Luiz Gonzaga de Castro Junior. - .

Piracicaba, 1998.

$105 \mathrm{p}$.

Tese (doutorado) - - Escola Superior de Agricultura Luiz de Queiroz, 1998.

Bibliografia.

1. Bovino de corte 2. Economia agricola 3. Indicador econômico 4. Liquidaçāo financeira 5. Mercado de futuros 6. Preço agricola 7. Produto agropecuário 8. Soja I. Título

CDD 338.176213 
Aos meus pais, Luiz e Maria,

\section{OFEREÇO}

A minha mulher, Lúcia,

DEDICO 


\section{Agradecimentos}

Aos professores do Departamento de Economia e Sociologia Rural da Escola Superior de Agricultura "Luiz de Queiroz" - USP, especialmente ao meu orientador prof. Pedro Valentim Marques, à profa. Mirian R.P. Bacchi, ao prof. João G.M. Filho, ao prof. Geraldo Sant'ana de C. Barros e ao prof. Carlos Tadeu dos S. Dias, do Departamento de Matemática e Estatística (DME/ESALQ), pela participação e valiosas sugestões, que muito contribuíram para o desenvolvimento e aperfeiçoamento desse trabalho.

Ao Centro de Estudos Avançados em Economia Aplicada da Fundação de Estudos Agrários "Luiz de Queiroz" (CEPEA/FEALQ) pela total disposição no fornecimento dos dados utilizados na condução dessa pesquisa.

Aos funcionários do DESR, Luciane, Helena, Maieli, Elenice, Marcia, Crico, Maria Helena, Valdeci e Pedro, pela convivência e total cooperação ao longo do curso de doutorado.

Aos meus pais, Luiz e Maria, que nunca mediram sacrifícios para que eu alcançasse meus objetivos; às minhas irmãs, Adriana e Érika, que levo no coração e na alma e agradeço por existirem; e, ao meu tio, Tomás de Aquino, que sempre me orientou em momentos cruciais da minha vida profissional.

Aos colegas do curso de doutorado e a todas as pessoas que, de uma forma ou outra, contribuíram para a realização desse trabalho. 


\section{SUMÁRIO}

Página

LISTA DE FIGURAS …………………...........................................

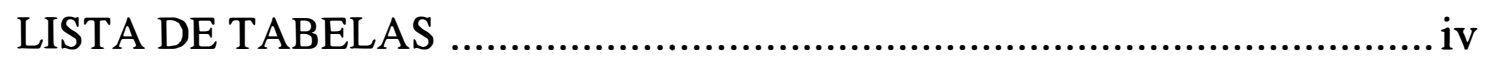

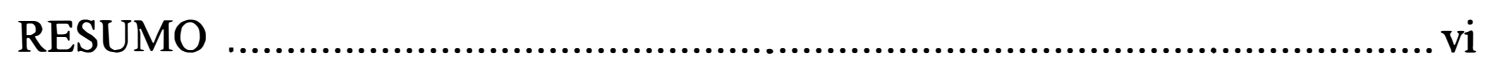

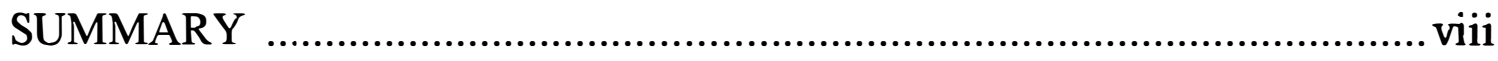

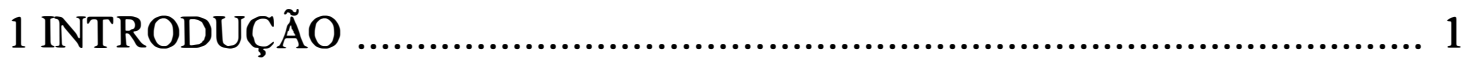

$1.1 \mathrm{O}$ problema e sua importância …………………………………….... 2

1.2 Objetivos ............................................................................... 3

2 FUNDAMENTAÇÃO TEÓRICA …………………………………..... 5

2.1 Conhecimentos sobre liquidação de contratos futuros............................... 5

2.2 Evolução da liquidação financeira nos contratos futuros ………………..... 10

2.3 Questões conceituais sobre a liquidação financeira ................................. 13

2.4 Formas alternativas de liquidação financeira ......................................... 15

2.4.1 Convergência de preços com liquidação física ...................................... 15

2.4.2 Convergência de preço com liquidação financeira obrigatória …............ 17

2.4.3 Combinação entre liquidação física e financeira ....................................20

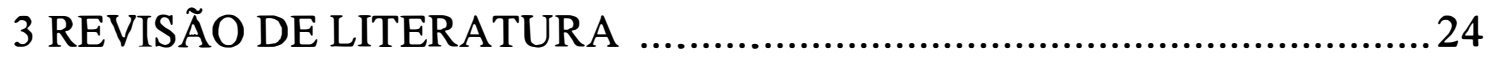

3.1 Contrato futuro de boi gordo no Brasil ..................................................24

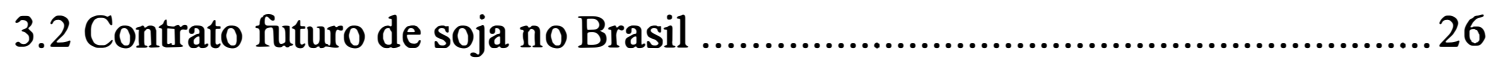

3.3 Trabalhos empíricos relacionados à liquidação financeira ……………......30

4 MATERIAL E MÉTODOS ................................................................. 41 
4.1 Modelo de preços futuros com opção de localização ................................... 41

4.2 Construção de um indicador ................................................................ 50

4.3 Avaliação da performance de hedging ................................................ 52

4.4 Testando modelos nonnested das especificações de liquidação .................... 55

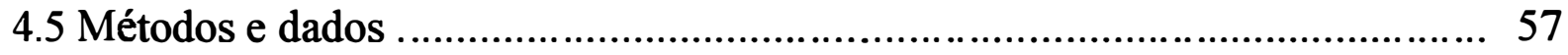

4.5.1 O caso da commodity boi gordo ...................................................... 57

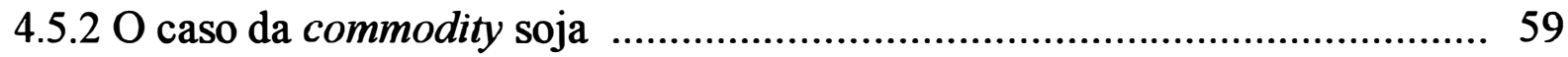

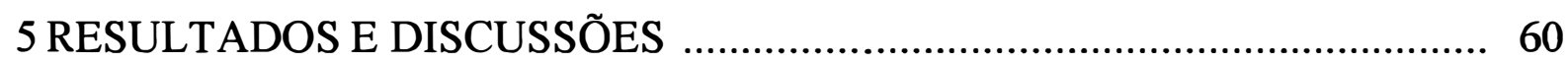

5.1 Análise dos resultados obtidos para os contratos de boi gordo ..................... 60

5.1.1 Eficiência de hedging medida entre os preços físicos de cada região e as formas de liquidação dos contratos

5.1.2 Variância da base entre os preços físicos de cada região e as especificações alternativas de liquidação

5.1.3 Resultados dos testes de hipótese com J-testes 66

5.2 Análise dos resultados obtidos para os contratos de soja cambial 67

5.2.1 Efíciência de hedging medida entre os preços físicos de cada região e as formas de liquidação dos contratos

5.2.2 Variância da base entre os preços físicos de cada região e as especificações alternativas de liquidação

5.2.3 Resultados dos testes de hipótese com J-testes 70

6 CONCLUSÕES 72

REFERÊNCIAS BIBLIOGRÁFICAS 75 APÊNDICES 


\section{LISTA DE FIGURAS}

Página

1 Convergência de preço com liquidação física 17

2 Convergência de preço com liquidação financeira obrigatória baseada em um indicador correto

3 Convergência de preço com liquidação financeira obrigatória baseada na possibilidade de indicador incorreto

4 Convergência de preço com entrega física e financeira combinada a um indicador com valor superior ao comercial

5 Convergência de preço com entrega física e financeira combinada a um indicador com valor inferior ao comercial

6 Evolução do número de contratos em aberto e do volume diário de contratos de boi gordo negociados na BM\&F, entre 1993 e 1996 


\section{LISTA DE TABELAS}

Página

1 Pesos regionais utilizados no cálculo do Preço Nacional da Soja FIPE/BM\&F

2 Ponderações regionais para o indicador de preços da soja ESALQ/BM\&F, 1997 30

3 Eficiência de hedging sobre especificações alternativas de liquidação - semana de vencimento

4 Variância da base entre o preço físico das regiões de estudo e as especificações de liquidação (AR, PCL, IEMB, IBG, PCLPD e IEMBPD) - semana do vencimento

5 Resultados dos testes de hipóteses para a commodity boi gordo - o número máximo de mercados onde pode-se não rejeitar a hipótese nula é oito 
6 Eficiência de hedging sobre especificações alternativas de liquidação

7 Variância da base entre o preço físico das regiões de estudo e os indicadores (NO, PCL, IEMB, PNS, IPS, PCLPD e IEMBPD) semana do vencimento

8 Resultados dos testes de hipóteses para a commodity soja - o número máximo de mercados onde pode-se não rejeitar a hipótese nula é três 


\title{
IMPACTOS DA LIQUIDAÇÃO FINANCEIRA SOBRE A EFICIÊNCIA DE HEDGING NOS CONTRATOS FUTUROS DAS COMMODITIES BOI GORDO E SOJA
}

\author{
Autor: LUIZ GONZAGA DE CASTRO JUNIOR \\ Orientador: Prof. PEDRO VALENTIM MARQUES
}

\section{RESUMO}

A liquidação financeira é um mecanismo que elimina praticamente todos os problemas inerentes à liquidação dos contratos futuros através da entrega física, conduzindo a um aumento em sua utilização por parte dos agentes do mercado. Frente a esse poder da liquidação financeira o problema principal que surge é a desconfiança dos participantes com relação ao indicador que representa o mercado físico.

Esse trabalho foi desenvolvido com o intuito de verificação dos impactos de diferentes formas de construção dos indicadores sobre os contratos futuros das commodities boi gordo e soja comercializados na BM\&F. As especificações analisadas foram as utilizadas atualmente: Indicador do Boi Gordo (IBG) e o Indicador do Preço da Soja (IPS); e, as formas alternativas: o Preço Nacional da Soja (PNS) antecessora do IPS, as ponderadas pela probabilidade da localização mais barata (PCL e IEMB) e as que consideram diferenciais de preços entre as localizações (PCLPD e IEMBPD). Os impactos foram medidos através 
da análise da eficiência de hedging e da variância da base entre as especificações e os preços físicos na semana de vencimento dos contratos. As regiões envolvidas, para o caso do boi, foram: Triângulo Mineiro (TM) - MG, Campo Grande (CG) - MS, Paranavaí/Maringá/Londrina (Maringá -NP) - PR, Goiânia (GO) - GO, Dourados (DO) - MS, Três Lagoas/Araçatuba (Araçatuba - AR) - SP, Presidente Prudente (PP) - SP, Bauru/Marília (Bauru - BA) - SP e São José do Rio Preto/Barretos/Votuporanga (São José do Rio Preto - SJ) - SP. As quatro últimas são regiões componentes da construção do indicador. Para a soja, as localizações participantes foram: Ponta Grossa (PG), Norte (NO), Oeste (OE) e Sudoeste (SO) do Paraná, sendo que a região de Ponta Grossa não participou da construção do indicador.

As principais conclusões que puderam ser tiradas através dos resultados obtidos foram: (1) todas as especificações de indicadores apresentaram alto grau de eficiência de hedging, tanto para a commodity boi gordo quanto para a soja; (2) a variância da base, entre os preços físicos locais e os indicadores avaliados, apresentou diferenças quanto à sua intensidade, onde detectou-se as especificações ponderadas pela probabilidade da localização mais barata e uma única localização como menor variância para o boi gordo e para a soja, respectivamente. 


\title{
IMPACTS OF CASH SETTLEMENT ON THE HEDGING EFFICIENCY IN FED CATTLE AND SOY COMMODITIES FUTURES CONTRACTS
}

\author{
Author: LUIZ GONZAGA DE CASTRO JUNIOR \\ Adviser: Prof. PEDRO VALENTIM MARQUES
}

\section{SUMMARY}

Cash settlement is a mechanism that eliminates, basically, all the problems inherent in the settlement of futures contracts through physical delivery, leading to an increase in its utilization by the market agents. Facing this power of cash settlement, the main problem arising is the distrust of the participants in relation to the indicator which represents the physical market.

This study was carried out aiming to verify the impacts of different forms of indicator constructions on the futures contracts of the fed cattle and soy commodities traded in the BM\&F. The specifications analysed were the ones currently in use: Fed Cattle Indicator (IBG) and Soy Price Indicator (IPS); and the alternative forms: National Soy Price (PNS) predecessor of the IPS, those pondered by the probability of cheaper location (PCL and IEMB) and the ones which consider price differentials between locations (PCLPD and IEMBPD). The impacts were measured through analysis of hedging efficiency and variance of 
the base between the specifications and the physical prices the week of the contract's expiration. The regions involved, for the cattle, were: 'Triângulo Mineiro (TM)-MG, Campo Grande (CG)-MS, Paranavaí/ Maringá/Londrina (Maringá-NP)-PR, Goiânia (GO)-GO, Dourados (DO)-MS, Três Lagoas/Araçatuba (Araçatuba-AR)-SP, Presidente Prudente (PP)-SP, Bauru/Marilia (Bauru-BA)-SP and São José do Rio Prêto/Barretos/Votuporanga (São José do Rio Prêto-SJ)-SP. The last four regions are components of the indicator construction. For the soy, the participating locations were: Ponta Grossa (PG), North (NO), West (OE) and Southwest (SO) of Paraná, although Ponta Grossa did not participate in the indicator construction.

The main conclusions drawn from the results obtained were: (1) all the indicators specifications presented a high degree of hedging efficiency, as much for the fed cattle commodity as for the soy; (2) the base variance between the local physical prices and the indicators evaluated presented differences as to its intensity, in which the specifications pondered by the probability of cheaper and a singular location as the lower variance for the fed cattle and soy, respectively, were detected. 


\section{INTRODUÇÃO}

O presente trabalho procura analisar os impactos da liquidação financeira sobre a eficiência de hedging nos contratos futuros das commodities boi gordo e soja comercializados na Bolsa de Mercadorias e Futuros de São Paulo (BM\&F). A eficiência de hedging pode ser medida como a redução percentual na variância de retornos alcançados por uma posição com hedge em oposição a uma sem.

Com o intuito de esclarecimentos relacionados ao que se pretende desenvolver, esse trabalho compõe-se de seis partes, sumariadas a seguir. Primeiramente procura-se evidenciar porque a importância do entendimento dos efeitos das especificações contratuais correntes e alternativas envolvendo a liquidação na expiração constitui um problema relevante, passível, portanto, de tornar-se objeto de tese de doutorado. Na segunda parte, busca-se caracterizar a evolução da liquidação de contratos futuros, além de apresentar questões de cunho conceptual e formas alternativas de liquidação.

A terceira constitui-se de uma revisão de literatura onde são considerados: a evolução dos contratos futuros do boi gordo e da soja no Brasil; a questão da metodologia empregada no desenvolvimento dos indicadores dessas commodities, utilizados, atualmente, para liquidar os contratos na BM\&F; e, os trabalhos empíricos relacionados à liquidação financeira. 
A quarta parte dedica-se especificamente à metodologia que será empregada na concepção desse trabalho, onde procede-se ao detalhamento referente a um modelo de preços futuros, à construção de um indicador alternativo, à avaliação da performance de hedging, aos testes empregados às especificações de liquidação, e aos métodos e dados utilizados. Finalmente, são apresentados na quinta e sexta partes os resultados e as conclusões, respectivamente.

\subsection{O problema e sua importância}

A função econômica de um mercado futuro é eficientemente desempenhada somente quando existe um alto nível de competição entre os participantes. Desse modo, a prevenção de distorções como corners $^{1}$ ou squeezes $^{2}$ tem sido uma área de grande interesse para as instituições de futuros.

A liquidação financeira elimina, completamente, os corners e os squeezes, além de reduzir os custos de transação incorridos na entrega física. Contudo, o principal problema com a liquidação financeira para as commodities agrícolas, refere-se à desconfiança com relação ao indicador que representa o

\footnotetext{
${ }^{1}$ De acordo com Hull (1991), corner é um tipo de irregularidade que ocorre quando um gnupo de investidores tenta assurnir uma enorme posição comprada a futuro e tentando igualmente exercer algum controle sobre a oferta do objeto de negociação. Quando o vencimento dos contratos futuros se aproxima, o grupo não encerra sua posição, e o número de contratos em aberto pode exceder a quantidade de mercadoria disponível para a entrega. Assim, os detentores de posições vendidas percebem que encontrarão dificuldade para entregar e ficam desesperados para zerar suas posições. $O$ resultado é uma grande alta nos preços futuro e à vista.

- 2 A situação de squeeze não configura a falta de mercadoria no mercado fisico como no corner, e caracteriza-se como uma situação onde o agente short (vendedor) em mercados futuros não consegue inverter sua posição ou adquirir a commodity para entregar, exceto por um preço substancialmente maior do que o valor relativo desse contrato ou dessa commodity no mercado (Downes \& Goodman, 1993; Bessada, 1995).
} 
mercado físico, criando uma incapacidade de previsibilidade da base. Além disso, tanto o boi gordo quanto a soja, são commodities amplamente produzidas em áreas geográficas dispersas, o que causa consideráveis incertezas em relação à base e à entrega física. Nesse contexto, o problema que urge, sob a pressuposição de liquidação financeira, relaciona-se aos impactos das diferentes formas de construção dos indicadores sobre a eficiência de hedging nos contratos futuros das commodities, especificamente, boi gordo e soja comercializados na Bolsa de Mercadorias e Futuros de São Paulo - BM\&F, que são objetos desse estudo.

A importância do entendimento dos efeitos das especificações contratuais correntes ( liquidação financeira - para o boi e a soja) e alternativas, envolvendo a liquidação na expiração é que no centro das distorções, encontra-se o tipo de sistema de liquidação associado aos contratos futuros.

\subsection{Objetivos}

O objetivo geral do trabalho será analisar o sistema de liquidação dos contratos de boi gordo e de soja comercializados na BM\&F, sendo que para isto os seguintes passos serão trabalhados: (1) adaptar e testar uma metodologia alternativa para a construção dos indicadores utilizados; (2) comparar a eficiência de hedging nos mercados utilizando os indicadores atuais (IBG e IPS), os indicadores baseados na condição de localização mais barata (EMB e IEMB), além do PNS (Preço Nacional da Soja) e os que utilizam apenas uma localização na sua construção (AR - região de Araçatuba; NO - região Norte do Paraná); (3) avaliar a variabilidade da base entre os tipos de indicadores e os preços físicos locais; e (4) realizar testes que possam sinalizar quais especificações são preferidas às outras. 
Esse estudo não pretende questionar a metodologia empregada no desenvolvimento dos indicadores utilizados atualmente na liquidação financeira dos contratos de boi gordo e de soja. O que se busca é testar um novo método que possa proporcionar possíveis contribuições ao aperfeiçoamento desses indicadores. 


\section{FUNDAMENTAÇÃO TEÓRICA}

\subsection{Conhecimentos sobre liquidação de contratos futuros}

Tradicionalmente, os contratos que não são previamente compensados $^{1}$ nos mercados futuros, são liquidados através da entrega ou recebimento do produto físico. A entrega da commodity comercializada é feita pelo vendedor para o comprador, em troca do pagamento do valor determinado pelo preço de ajuste a futuro do comprador para o vendedor. Esse processo é visto como de fundamental importância na promoção da convergência dos preços físico e futuro, que por sua vez, aumenta a transferência de risco e a função de descoberta de preço dos mercados futuros. A não ocorrência da convergência de preços durante o período de entrega, proporcionará uma oportunidade de ganhos com a arbitragem. Isto é, se o preço futuro fosse maior do que o preço a vista, arbitradores comprariam a commodity no mercado físico e a venderiam a futuro onde receberiam um preço mais alto. Por outro lado, se o preço a futuro fosse menor que o a vista, os arbitradores comprariam o contrato futuro e venderiam a commodity no mercado físico, recebendo a commodity no contrato futuro de compra e repassando-a aos compradores no mercado físico.

\footnotetext{
${ }^{1}$ Compradores e vendedores invertem suas posições no mercado futuro antes do vencimento do contrato, isto é, se um hedger fez um contrato de venda, ele simplesmente adquire um contrato de compra, para 0 mesmo vencimento, zerando sua posição e saindo do mercado. Por outro lado, se ele tiver um contrato de compra, vendendo um contrato equivalente ele zera sua posição e sai do mercado.
} 
A respeito da aparente importância do processo de entrega física para os mercados futuros, Leuthold et al. (1989) colocam que menos de $2 \%$ de todos os contratos são liquidados fisicamente. De fato, compradores e vendedores, geralmente, eliminam suas obrigações invertendo as posições antes do vencimento do contrato. Essa operação produz um simples ajuste financeiro de ganhos e perdas e, o mais importante, evita os custos e as incertezas de se entregar ou receber a commodity.

Os custos associados com a entrega física e a conveniência da compensação têm induzido várias propostas para substituir a entrega física pela liquidação financeira em certos tipos de contratos. A liquidação financeira é uma alternativa à entrega física, para cumprir as obrigações contratuais quando do vencimento de um contrato futuro. Tipicamente, o valor da última liquidação é baseado em algum indicador físico, determinado por uma fórmula relacionada aos preços do mercado físico, independente do mercado futuro. Na prática, quando um contrato é liquidado financeiramente, e sendo todos os valores determinados no mercado diariamente, o total pago entre compradores e vendedores no término, é a diferença entre o valor do indicador do mercado físico no último dia ou média dos últimos dias de negociação e o preço de ajuste do contrato no dia anterior.

Existem algumas diferenças conceituais básicas entre os mecanismos de entrega física e de liquidação financeira (Jones, 1982). Primeiramente, a liquidação física possui como propósito básico a garantia de convergência dos preços físico e futuro durante o período de entrega, sendo essencial na determinação do preço e na criação dos hedges efetivos. No caso da liquidação financeira, a arbitragem entre físico e futuro não se faz necessária na obtenção da convergência de preços, uma vez que essa é imposta através do 
ajustamento do preço futuro ao indicador do mercado físico no dia de vencimento do contrato. Assim, para Barros et al. (1997), um indicador representativo ${ }^{2}$ do preço da commodity é essencial para que esse mecanismo seja eficiente. Para esses mesmos autores, além dessa característica, outras duas propriedades são desejáveis em um indicador: a visibilidade ${ }^{3}$ e o potencial de credibilidade ${ }^{4}$.

Segundo, os fluxos de capital são diferentes. Na entrega física, o capital relativo ao valor total dos contratos muda de mãos entre compradores e vendedores remanescentes no mercado e que desejam participar da entrega, após cessadas as negociações. Relacionado à liquidação financeira, sob a hipótese de que no último dia os preços físicos e futuros se igualam, a mudança do fluxo de dinheiro ocorre somente nesse dia, e corresponde, simplesmente, ao ajuste feito entre o preço final determinado no mercado e o preço relativo ao contrato negociado.

A terceira diferenciação esta associada às duas anteriores, onde diz que sob liquidação financeira, tanto o vendedor quanto o comprador podem negociar no mercado físico se desejarem. Isto faz com que não necessariamente

\footnotetext{
${ }^{2}$ Para que um indicador possua representatividade, ele precisa figurar um mercado ou região relevante do ponto de vista de produção, processamento e exportação.

${ }^{3}$ A visibilidade é usada para medir o grau com que o indicador reflete os preços praticados (preços de negociação) no mercado (conjunto de praças). Assim, um indicador, que é reputado com boa visibilidade, facilita a sua aceitação para fins de liquidação dos contratos, recuzindo as contestações e questionamentos, além de permitir aos operadores se concentrarem na elaboração de estratégias de atuação no mercado futuro. Os principais fatores que influenciam a visibilidade são: o tamanho do mercado considerado e a variabilidade de preços. Em geral, mercados menores tendem a ter melhor visibilidade.

${ }^{4} \mathrm{O}$ potencial de credibilidade refere-se ao grau com que o indicador tende a ser aceito à medida em que for sendo utilizado pelos participantes do mercado. A capacidade de auto-previsão do indicador e, também, a sua capacidade de prever os preços de outras regiões, que possam querer utilizá-lo para liquidação de contratos, são os instrumentos utilizados para tentar medir esse potencial.
} 
exista fluxo de dinheiro entre eles, tornando opcional a cada participante a entrada ou não no mercado físico. Essa ausência de preocupação em entregar (receber) o produto físico, reduz a pressão sobre o vendedor (comprador), podendo alterar a composição dos negociadores remanescentes no mercado no último dia. Por outro lado, sob entrega física, a troca do produto é obrigatória

Finalmente, a quarta diferenciação infere que sob liquidação física o valor da negociação é baseado no preço determinado no mercado futuro, enquanto na liquidação financeira o valor do produto é estipulado por algum valor do indicador físico, sendo que para as commodities agrícolas, esse pode diferir substancialmente de região para região em relação ao indicador de preços.

A liquidação financeira foi implementada no final dos anos 60 e início dos 70 em produtos perecíveis (boi e frango) na Chicago Board of Trade (CBOT). Contudo, essas tentativas iniciais fracassaram por várias razões, entre elas está a não aprovação da Commodity Exchange Autority, a falta de aceitação ou conviç̧ão dos negociadores e indústrias, e a não especificação da liquidação financeira como obrigatória, em vez de deixá-la como característica opcional (Paul, 1985).

Uma outra grande modificação ocorrida no contrato de boi negociado nos EUA, foi o Sistema de Certificado de Entrega. De acordo com Leuthold (1992), o ímpeto para mudar veio da contínua relutância de compradores a futuro participarem do mercado e da reentrega do boi. Assim, o Sistema de Certificado foi eventualmente aprovado e tornou-se efetivo nos contratos de boi em dezembro de 1983 na Chicago Mercantil Exchange (CME). Esse tipo de 
liquidação permaneceu em atividade até setembro de 1986, quando foi substituído pela liquidação financeira.

O Sistema de Certificado consistiu dos seguintes passos, relatados por Purcell e Hudson (1986): (1) o mantedor da posição vendida que desejasse entregar a commodity, ofereceria um certificado indicando a localização planejada da entrega; (2) a bolsa designaria o certificado para o comprador com maior tempo no mercado, que também aceitasse receber a commodity ou reter o certificado, pagando uma taxa de $\$ 1.50$ por arroba; (3) a taxa seria acumulada, anexada ao certificado, e serviria para prover um eventual comprador que aceitasse receber a commodity; (4) cada certificado poderia ser retido no máximo três vezes, sugerindo um total possível de contribuição ou "valor do certificado" de $\$ 4.50$ por arroba; e, (5) um comprador poderia emitir uma "notícia de demanda" especificando onde ele estaria disposto a aceitar a entrega. A "notícia de demanda" moveria o comprador para "o início da linha", dando prioridade sobre todos os outros pretendentes, e garantindo seu acesso à commodity.

O Sistema de Certificado possuía duas importantes mudanças relativas ao sistema de entrega física. A primeira, é que a "notícia de demanda" permitiu ao comprador interessado em aceitar a commodity especificar a localização onde a entrega deveria ser realizada, e a segunda, é a eliminação da desmotivação para reentregar os animais através da transmissão do Certificado em vez da commodity. A proposta original sofreu modificações tentando reduzir o tempo no processo de entrega, almejando com isso, diminuir o risco e as incertezas, especialmente para os arbitradores envolvidos no processo. $\mathrm{O}$ fato, de acordo com Purcell e Hudson (1986), é que a base estava alargada e que não houve uma redução significativa na variância em muitos pontos de entrega. 
Contudo, isso não é caracterizado como falhas do Sistema de Certificado, uma vez que os problemas estavam localizados no tipo de administração do sistema e são condições que prevalecem sobre as prioridades de mudanças. Desse modo, na tentativa de abrir a porta para a participação do comprador, barreiras foram impostas aos vendedores.

\subsection{Evolução da liquidação financeira nos contratos futuros}

A liquidação financeira é o último elo, em uma longa corrente de desenvolvimentos históricos, que tem conduzido a negociação a futuro para um mercado mais trabalhado. Quando aplicada para uma commodity física, por exemplo grãos, os desenvolvimentos, de acordo com Paul (1987), incluem: melhoria nos padrões de classe; melhor regulamentação da emissão e transferência de recebimentos dos armazéns, posteriormente, a substituição desses recebimentos pelas notícias de entrega, que passaram a circular no local de negociação; a provisão para a entrega substituta; o uso da "chamada de liquidação" voluntária; a criação da câmara de compensação para substituir a chamada de liquidação voluntária, sendo essa última evolução, o principal garantidor dos contratos futuros; e, muitas outras alterações que têm facilitado o processo de liquidação através da compensação dos contratos futuros, que é preferível à entrega física.

Todos os contratos futuros atualmente possuem ao menos alguma das seguintes cláusulas de liquidação financeira parcial, citadas por Garbade e Silber (1983a): (1) liquidação por compensação; (2) liquidação por uma troca de futuros por físicos (com um pagamento se necessário); (3) liquidação por entrega 
física desigual com um ajustamento financeiro; e, (4) liquidação financeira na ocorrência de um corner ou squeezes na commodity entregável.

Das cláusulas citadas acima, tem-se que as duas primeiras são escolhas voluntárias entre compradores e vendedores como uma forma de diminuir os custos e incertezas de se fazer ou receber uma entrega física. As duas últimas são opções relacionadas aos vendedores e são atribuíveis aos casos em que os squeezes e corners estão associados à entrega física.

Relacionado à liquidação por compensação, tem-se que a utilidade de um contrato como uma devida negociação, é estabelecida quando a especificação da classe da commodity e a localização de entrega igualam-se às práticas do comércio. Uma vez o potencial de negociação do contrato sendo estabelecido, os preços físicos e futuros se moverão juntos. Dado esse movimento conjunto, mais participantes tentarão evitar a entrega física. Adicionalmente, temse que especuladores não comerciais, sempre tentarão evitar transações de entrega pela não familiaridade relativa aos mercados físicos. Essas preferências são as principais razões porque muitos contratos futuros são liquidados por compensação, com o pagamento feito ou recebido dependendo da diferença entre os preços de compra e de venda de um contrato.

A segunda prática envolvendo a liquidação financeira parcial é conhecida como uma "troca de futuros para físicos". Nessas transações, um estoque da commodity que não é entregável sob os termos de um contrato futuro (tal como grãos classificados com padrões inferiores) é usado para liquidar uma posição de venda futura. Uma vez que a commodity não é contratualmente entregável, o comprador precisa concordar voluntariamente em aceitar a entrega, 
incluindo uma negociação privativa para o ajuste refletir a diferença entre o preço da commodity padronizada e o preço da que foi entregue. O principal objetivo desse tipo de alternativa, é reduzir os custos de entrega, permitindo aos vendedores organizarem entregas possíveis da commodity, respeitando sua qualidade e localização.

A busca por alternativas de entrega que evitassem os squeezes e, mais genericamente, aumentos de preços por precauções acumulativas de estoques entregáveis, fez com que um maior número de contratos estabelecessem opções para vendedores entregarem classes não padronizadas em localizações alternativas. Nesse tipo de mecanismo, as especificações contratuais premiam e descontam as entregas feitas nessas classes e localizações, bem como compensam compradores que aceitam receber tais commodities.

A possibilidade de squeezes e corners torna-se mais "sinistra" quando um esforço intencional é feito para controlar ou monopolizar a oferta entregável de uma commodity. Para desencorajar tais disfunções de preços intencionais, os contratos futuros estão equipados para liquidar financeiramente quando a reclamação de um corner por um membro de uma bolsa é sustentado por um comitê de arbitragem. Tal providência de emergência elimina a necessidade de entrega física, mas são medidas ex-post e arbitrárias. Desse modo, torna-se necessário enfatizar uma medida ex-ante para eliminar totalmente os problemas de corners. 


\subsection{Questões conceituais sobre a liquidação financeira}

A liquidação financeira, de acordo com Paul (1985), levanta várias questões interrelacionadas: o propósito econômico a que serve; o efeito sobre o comportamento do preço; o risco da base e a eficiência de hedging; o potencial de manipulação do indicador; e, o desempenho dos reguladores. Jones (1982) coloca que a condição suficiente, para que a liquidação financeira seja um meio possível para liquidar contratos futuros, é a existência de um "bom" preço no mercado físico, que possa ser usado como uma base para determinar o preço de liquidação a futuro. Para esse mesmo autor, um "bom" preço no mercado físico é definido como sendo: uniforme e representativo de um padrão industrial; bem conhecido e amplamente acessível; um indicador correto do preço da commodity; e, imune à manipulação.

Os contratos futuros são bem sucedidos, somente se os preços a vista e futuro convergirem para o valor comercial $^{5}$ da commodity no seu vencimento. Com a entrega física, a convergência do preço é comumente assegurada através da arbitragem. Os obstáculos a esse processo podem ocorrer se os custos de entrega são elevados ou se negociadores esperando fazer ou receber a entrega, distorcem o preço a vista da commodity entregável (Jones, 1982; Garbade e Silber, 1983a; Kahl et al., 1989). Uma vez que a liquidação financeira não requer a entrega física, Jones (1982) afirma que essa pode reduzir, se não eliminar totalmente, o potencial de squeezes e corners nos contratos futuros. Se a oferta entregável no contrato futuro é inadequada, o impacto potencial da liquidação financeira em prevenir a potencialidade de tais disfunções é muito importante.

\footnotetext{
${ }^{5}$ é o preço da commodity no mercado físico, determinado através das leis de oferta e demanda, isto é, em um mercado concorrencial.
} 
Contudo, se a oferta desejável é inadequada, os preços no mercado físico, que serviriam de base para o indicador podem ser manipulados. Nesse caso, com a liquidação financeira, a manipulação do mercado futuro poderia ocorrer indiretamente, pela manipulação do mercado físico.

Através da liquidação financeira, pode ser possível a expansão da faixa de classe de produto para aumentar a oferta entregável. Apesar disso, é controverso sob qual cenário a base pode ser mais previsível. De acordo com Kahl et al. (1989), o preço futuro de um contrato com entrega física com múltiplas classes de entrega e localizações, usualmente é representado pelo valor da commodity entregável mais barata (isto é, a classe e/ou ponto de entrega mais barato), enquanto que o preço futuro de um contrato liquidado financeiramente representa o valor médio das classes e/ou pontos de entrega. Assim, para assegurar um indicador representativo, é feito uma ponderação sobre os vários preços do mercado físico, representando múltiplas classes e localizações. Alguns autores argumentam que os preços médios mudam menos que os preços da classe entregável mais barata, fazendo a base menos variável e mais previsível sob a liquidação financeira, que pode melhorar a eficiência de hedging (Jones, 1982; Lien, 1989; Kahl et al., 1989). Contudo, Leuthold (1992) conjectura que existem mais variáveis entrando na composição, ficando mais difícil correlacionar um dado preço do mercado físico com o indicador. Além do que, a melhora na previsibilidade da base sob liquidação financeira pode não ser verdade para um hedger individual em uma localização distante, que continuamente produz commodities de classe entregável mais barata.

Várias melhorias na contribuição dos contratos futuros para a prosperidade econômica, podem ser obtidas através da implementação do 
mecanismo de liquidação financeira (Garbade e Silber, 1983a). Entre essas, podem ocorrer melhorias na previsibilidade da base, aumentando a eficiência de hedging; redução nos custos diretos através da eliminação da entrega física no dia da liquidação; além de permitir flexibilidade no planejamento dos contratos futuros. Contudo, a exigência que se faz é a necessidade de um indicador seguro que represente fielmente o valor comercial da commodity e que possua as características de visibilidade e credibilidade. O não cumprimento dessas exigências, coloca a liquidação financeira em uma posição inferior à entrega física em termos de risco da base e eficiência de hedging.

\subsection{Formas alternativas de liquidação financeira}

As formas alternativas de liquidação financeira apresentadas por Garbade e Silber (1983a), incluem: a obrigatória, a opcional com uma penalidade, e a opcional sem penalidade. A análise, realizada por esses autores, mostra que a escolha entre essas alternativas depende, basicamente, de três fatores: (1) a necessidade de promover a convergência dos preços físicos e futuros devido aos altos custos de entrega; (2) a necessidade de reduzir a incidência de squeezes e corners; e, (3) se o indicador é incorreto e/ou sujeito a manipulações.

\subsubsection{Convergência de preços com liquidação física}

Existem dois problemas primários com a entrega física. Primeiramente, o alto custo de entrega que prejudica a convergência dos preços no mercado a vista e a futuro com o contrato aproximando-se da data de 
expiração. Para ilustrar esse ponto, suponha um contrato próximo da liquidação, e o preço da commodity no mercado físico sendo menor que o preço futuro por um total substancial. Ignorando os custos de transação, um arbitrador poderia adquirir a commodity física, vender um contrato futuro, e liquidar o contrato entregando a commodity. Para melhor exemplificar, suponha que o preço a vista da arroba do boi seja US\$24,00 e o preço futuro igual a US\$ 26,00, tais valores proporcionaria uma condição de arbitragem onde haveria um lucro sem risco de US\$2,00/@. Contudo, se o custo de entrega da commodity boi gordo for de US\$ 3,00/@, a arbitragem pode não ocorrer e consequentemente a convergência de preço não necessariamente existirá.

O segundo problema, é que demandas por precauções cumulativas realizadas pelos vendedores, preparando para entregar a commodity, podem elevar os preços no mercado físico local de classes entregáveis. $O$ resultado é que o squeeze aumenta o preço no mercado físico, no ponto de entrega, acima do verdadeiro valor comercial da commodity.

Os problemas de convergência descritos acima, são ilustrados pela Figura 1. De forma ideal, os preços físico e futuro se igualariam ao valor comercial da commodity na data de liquidação - ponto em que a linha bb cruza o eixo vertical e ponto de $45^{\circ}$ na linha aa, respectivamente. Assim, haveria uma convergência de ambos os preços para o ponto X, Figura 1.

A presença de altos custos de entrega prejudicaria a arbitragem físico/futuro, onde, dependendo de suas magnitudes, o preço futuro pode estar 
posicionado acima ou abaixo do preço físico ( $\mathbf{c}_{1}$ e $\mathbf{c}_{2}$ na Figura 1$)^{6}$. A combinação dos preços físico e futuro, portanto, se dará em algum lugar da região A. Além disso, squeezes e corners podem causar variações no preço físico, que assumirá valores maiores ou menores do que o valor comercial da commodity, expandindo a linha bb para a região B. O efeito líquido se dá em algum lugar dentro da região sombreada, isto é, onde ocorre a interseção das regiões A e B, Figura 1.

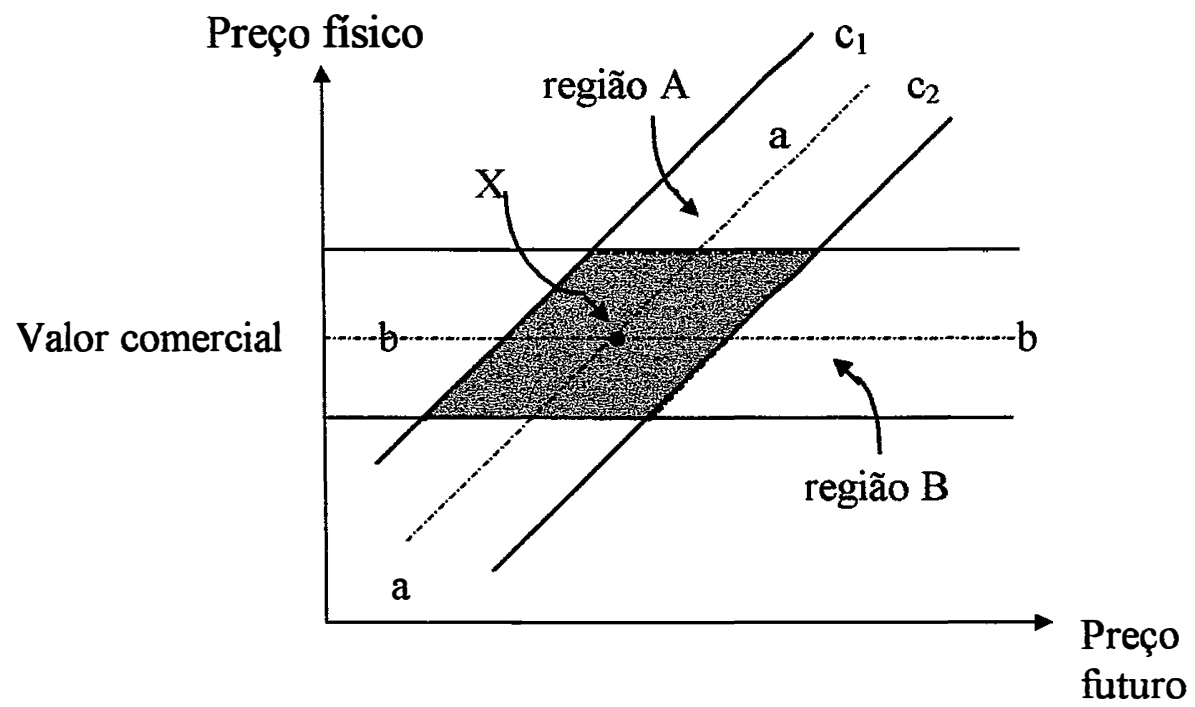

Figura 1: Convergência de preço com liquidação física.

Fonte: Garbade e Silber (1983a).

\subsubsection{Convergência de preços com liquidação financeira obrigatória}

A liquidação financeira obrigatória, sendo realizada através da utilização de um indicador seguro e livre de influências manipulativas, eliminará os problemas ilustrados na Figura 1. Como os contratos futuros não permitem a

\footnotetext{
${ }^{6} c_{1}$ é o custo de transação de comprar no mercado físico e entregar um contrato futuro. $c_{2}$ é o custo de transação de vender no mercado físico e receber um contrato futuro.
} 
entrega física, os squeezes e corners desaparecem e os preços no mercado físico local de classes entregáveis não divergirão do valor comercial da commodity. Assim, a região $\mathbf{B}$ na Figura 1 se resume à linha bb na Figura 2, indicando que o preço físico sempre se igualará ao verdadeiro valor comercial da commodity no ponto $\mathrm{X}$.

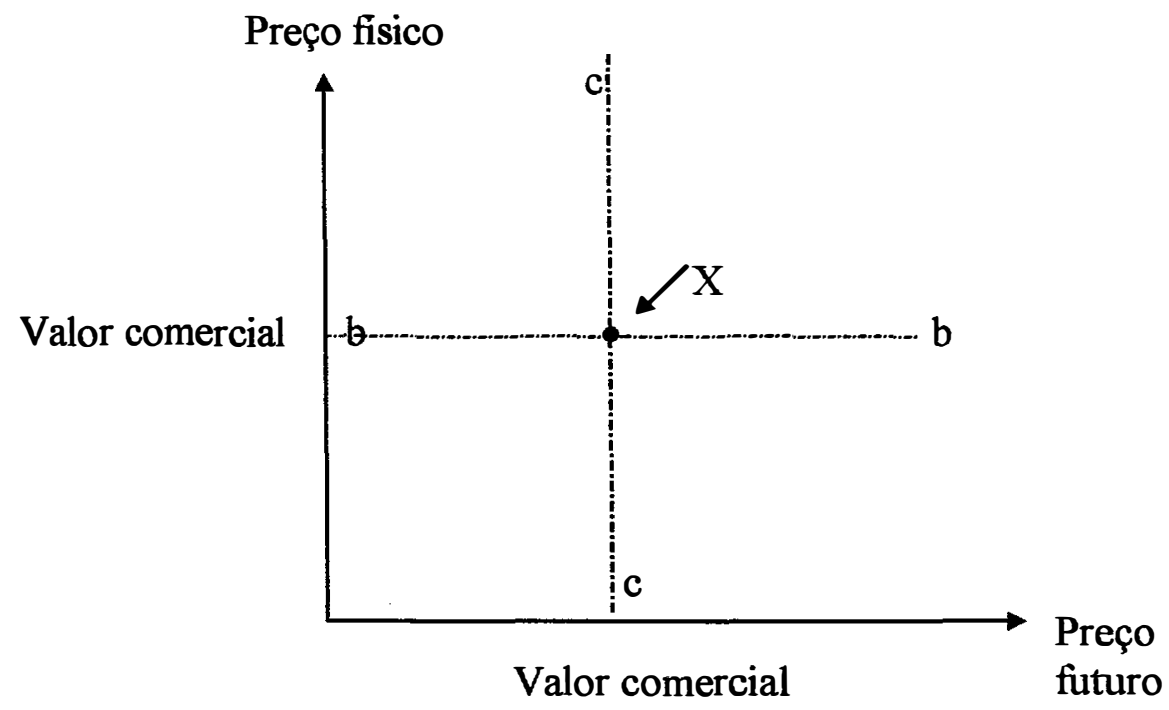

Figura 2: Convergência do preço com liquidação financeira obrigatória, baseada em um indicador correto.

Fonte: Garbade e Silber (1983a).

Um outro ganho com a liquidação financeira é que as transações sem risco no mercado futuro forçam o preço futuro à igualdade com o indicador no dia da liquidação. Se o preço futuro está acima do indicador, arbitradores venderão contratos futuros para ganhar o ajuste entre o preço futuro e o indicador, pressionando para baixo o preço futuro. Inversamente, se o preço futuro está abaixo do indicador, arbitradores comprarão contratos futuros o que pressionará os preços futuros para cima. Portanto, se o indicador representa corretamente o valor comercial da commodity, o preço futuro também convergirá para o 
verdadeiro valor comercial. Na Figura 2, isto implica que o preço futuro estará sobre a linha cc.

A liquidação financeira torna-se preferencial dependendo da exatidão com que o indicador mede o valor comercial da commodity. A Figura 3 ilustra o problema criado pela medição enviesada do indicador. Supondo que esse possa tomar qualquer valor na $b a n d a^{7}$ dd em torno do valor comercial e desde que o preço futuro precise convergir para o indicador, a combinação de preços físico/futuro precisa estar dentro da região D. O fato é que os preços físicos nunca divergem do verdadeiro valor comercial (squeezes e corners não existem), assim, a combinação possível de preços físico e futuro fica em algum ponto na linha ee.

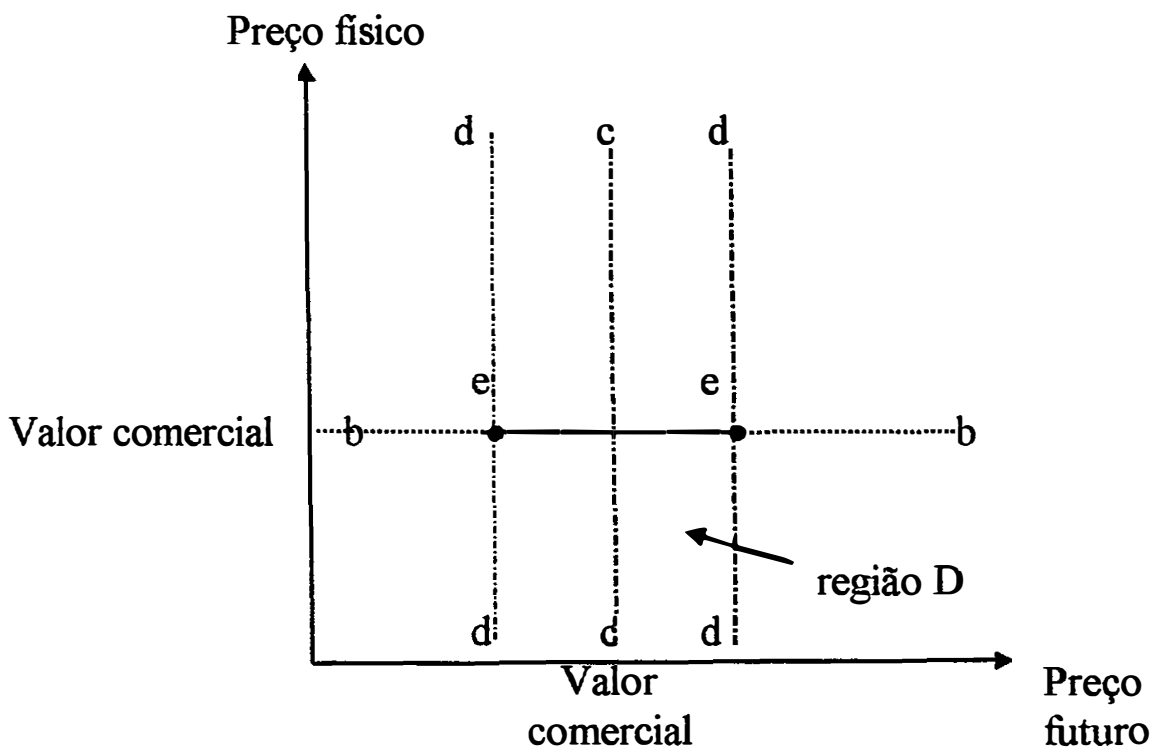

Figura 3: Convergência de preço com liquidação financeira obrigatória baseada na possibilidade de indicador incorreto.

Fonte: Garbade e Silber (1983a).

\footnotetext{
${ }^{7}$ A largura dessa banda refletirá o quanto o mercado está sujeito a influências manipulativas.
} 
A escolha entre liquidação física e financeira com um indicador imperfeito, é essencialmente um assunto de escolha entre (a) a convergência para a região sombreada na Figura 1 e (b) a convergência para a linha ee na Figura 3. Os casos extremos são os seguintes: se a linha ee na Figura 3 é curta (indicador bastante correto) e se as regiões A e/ou B na Figura 1 são largas (os custos de entrega são altos e/ou squeezes prováveis), então a liquidação financeira é preferida. Contrariamente, a liquidação financeira não é desejável se o indicador é incorreto (linha ee longa), os custos de entrega são baixos e as distorções de preço devido aos squeezes e corners são improváveis (região sombreada na Figura 1 é pequena).

\subsubsection{Combinação entre liquidação física e financeira}

Analisando contratos futuros com provisões para liquidação financeira e física, sem nenhum tipo de penalidade para ambas as formas, observa-se a necessidade de regras de preferências para resolver impasses entre aqueles participantes que preferem liquidação física e os que desejam a financeira. Como as transações sem risco dentro dos mercados futuros forçam o preço futuro para o indicador na data de liquidação, ponto indicado pela interseção entre a linha ff e o eixo horizontal, e desde que não exista razão para distorções no preço físico, a combinação inicial dos preços físico/futuro é representada pelo ponto Y na Figura 4.

Assumindo que o erro no indicador (distância entre as linhas cc e ff) exceda os custos de transação da commodity $\left(\mathbf{c}_{1}\right)$, a combinação dos preços físico/futuro não pode permanecer no ponto $\mathbf{Y}$. Em particular, desde que o preço 
futuro exceda o preço a vista por mais que os custos de transação naquele ponto, arbitradores comprarão a commodity no mercado físico e venderão a futuro para fazerem a entrega. Essas transações elevarão o preço no mercado físico e redurirão o preço futuro. Contudo, o efeito sobre o preço futuro será compensado pelos arbitradores no mercado futuro que, antecipando a liquidação financeira, comprarão contratos futuros tão logo os preços futuros caiam abaixo do indicador. Assim, o efeito da arbitragem com o mercado físico, é somente para aumentar o preço físico até esse se igualar ao preço futuro menos os custos de entrega, ficando a combinação de preços no ponto $\mathbf{Z}$ da Figura 4 .

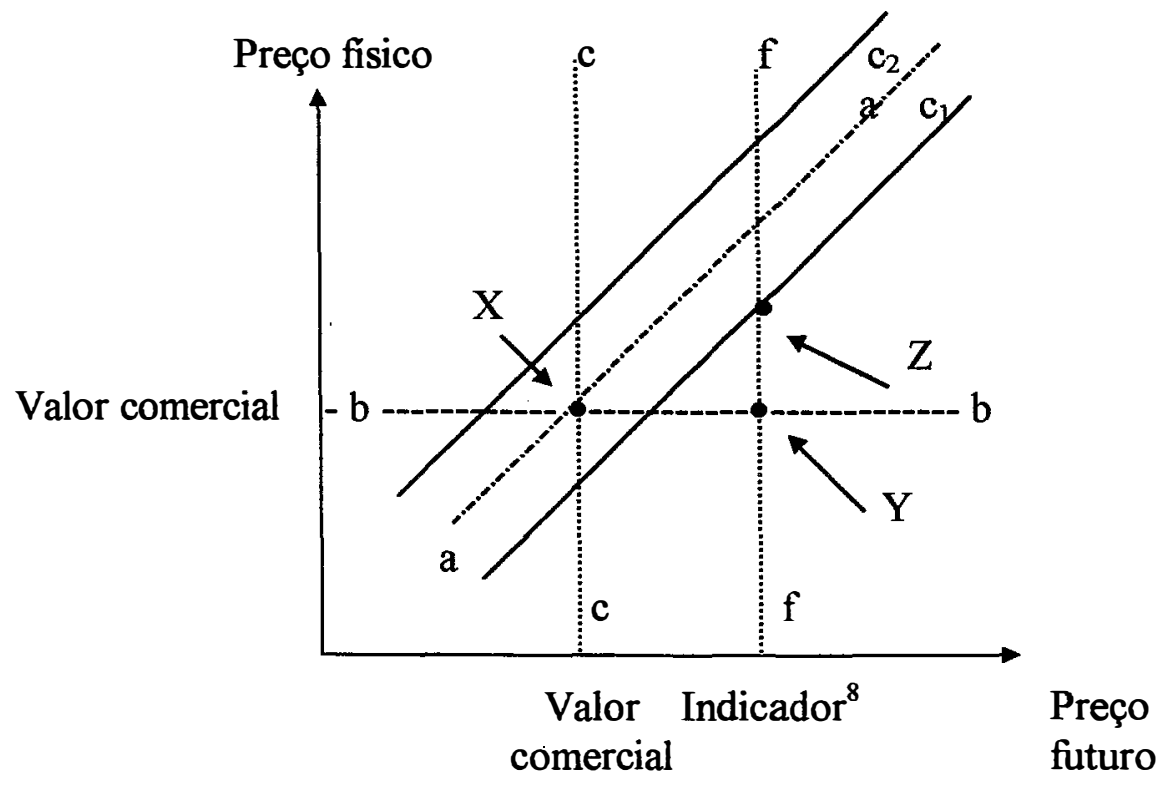

Figura 4: Convergência de preço com entrega física e financeira combinada a um indicador com valor superior ao comercial.

Fonte: Garbade e Silber (1983a).

No caso onde o preço a vista excede o preço futuro por mais que os custos de transação, o processo será invertido ao apresentado na Figura 4. Os

\footnotetext{
${ }^{8}$ Erro de medida do indicador em relação ao valor comercial da commodity.
} 
arbitradores venderão a commodity no mercado físico e comprarão a futuro, provocando, como resultado líquido, a redução do preço físico, igualando-o ao preço futuro mais o custo de entrega (ponto $\mathbf{Z}^{\prime}$ ), Figura 5.

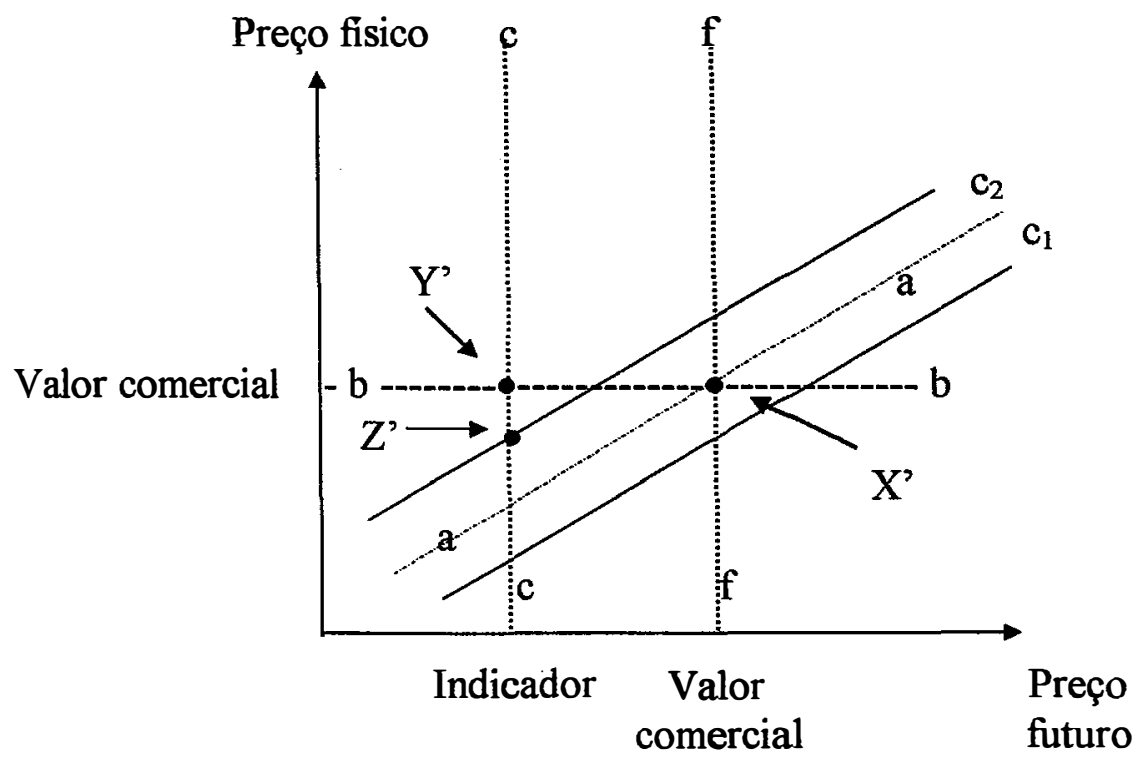

Figura 5: Convergência de preço com entrega física e financeira combinada a um indicador com valor inferior ao comercial.

Fonte: Desenvolvido com base no trabalho de Garbade e Silber (1983a).

A constatação mais significativa é que possibilitando a liquidação física ou financeira sem penalidades, com um indicador incorreto, criará uma inconsistência nas intenções de compradores e vendedores. No caso indicado pela Figura 4, os vendedores escolherão entregar a commodity enquanto compradores tentarão liquidar os contratos financeiramente. Por outro lado, ao se observar a Figura 5, pode-se inferir o contrário, onde, os vendedores desejarão liquidar financeiramente os contratos enquanto os compradores optarão receber a commodity física. Desde modo, uma determinada forma de liquidação precisa ser priorizada. 
Permitindo àquele que deseja entregar a commodity impor a sua opção, todos os benefícios da liquidação financeira seriam perdidos, implicando que um participante do mercado futuro nunca poderia estar certo de evitar os custos de fazer ou receber a entrega física. Assim, se o preço futuro exceder de longe o valor do indicador, um arbitrador relutaria vender um contrato caso os compradores estivessem demandando a entrega física. 


\section{REVISÃO DE LITERATURA}

\subsection{Contrato futuro de boi gordo no Brasil}

O mercado futuro de boi gordo no Brasil, foi inicializado em 1981, relançado em 1991, e a partir daí, vem sofrendo inúmeras restruturações, principalmente, com relação contratual e padrões internos de negociação. As duas principais alterações nesse mercado foram: a instituição de um local específico para entregas físicas (curral em Araçatuba - supervisionado pela BM\&F) e, a utilização da liquidação financeira nos contratos. A primeira teve um período curto de vigência, sendo que os vencimentos que apresentaram essa alteração foram os de outubro/dezembro de 1994 e de março/maio de 1995.

A segunda alteração foi instituída no final de 1994, para um contrato com vencimento em agosto de 1995 (ver apêndice 1). O indicador utilizado, nesse mecanismo, é cotado e calculado pela Escola Superior de Agricultura Luiz de Queiroz (ESALQ), especificamente, pela Fundação de Estudos Agrários Luiz de Queiroz (FEALQ) através do Centro de Estudos Avançados em Economia Aplicada (CEPEA). A importância dessas duas alterações, pode ser mensurada através do desempenho no volume negociado e no número de contratos em aberto (Figura 5), onde pode-se observar, claramente, um 
aumento significativo na negociação de contratos quando de suas implementações.

$\mathrm{O}$ indicador $\mathrm{BM \& F} / \mathrm{BOI} / \mathrm{ESALQ}^{7}$, é um indicador diário do preço do boi gordo no Estado de São Paulo. Trata-se de uma média ponderada dos preços de quatro grandes regiões produtoras (Presidente Prudente, Araçatuba, Baun/Marília e São José do Rio Preto/Barretos) no Estado. As informações diárias são os preços do boi gordo e, também, as escalas de abate. Esse último, consiste no período transcorrido entre a contratação do abate e sua efetiva realização, sendo esse acrescido ao prazo corrente de pagamento.

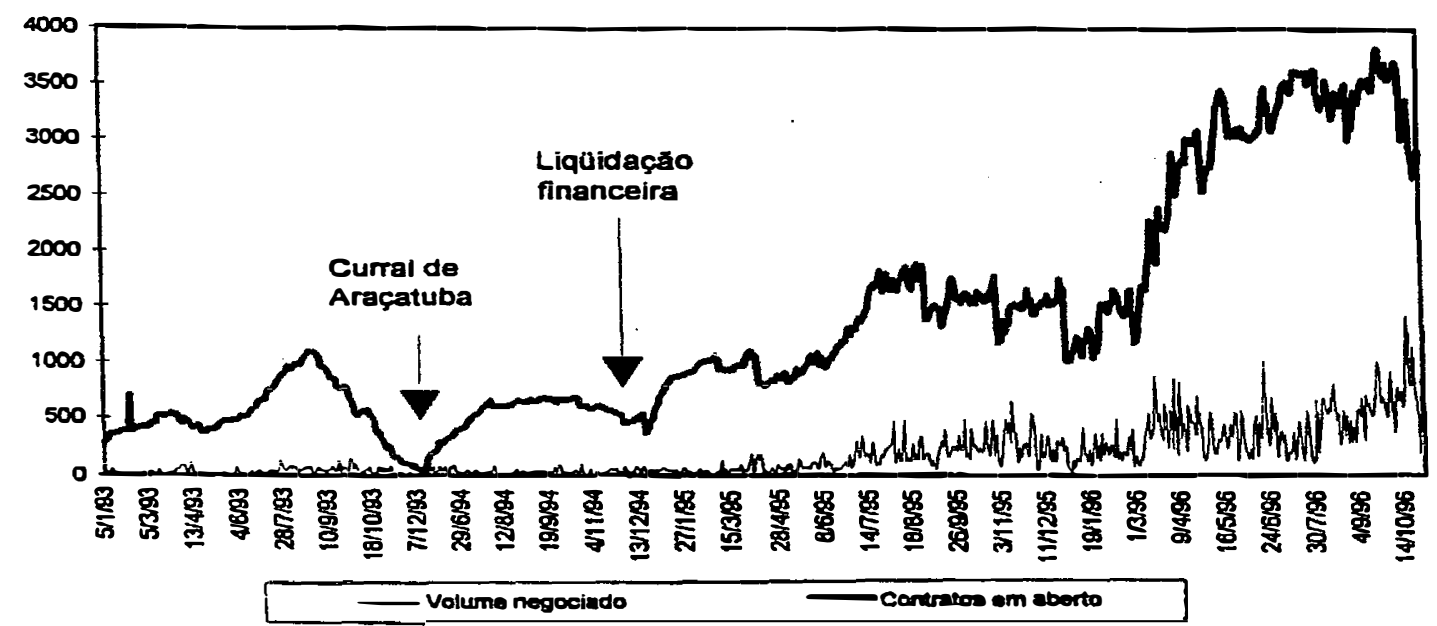

Figura 6 - Evolução do número de contratos em aberto e do volume diário de contratos de boi gordo negociado na BM\&F, entre 1993 e 1996.

Fonte: BM\&F (1997).

Através da taxa média de desconto dos Certificados de Depósitos Interbancários (CDI), os preços nominais levantados são descontados pelo prazo citado anteriormente, gerando o preço a vista. A seguir, calcula-se a média

\footnotetext{
${ }^{7}$ Texto baseado em Barros et al. (1994).
} 
aritmética dos preços obtidos em cada região, gerando-se assim os preços regionais. Posteriormente, esses preços são ponderados pela importância de cada região na quantidade de abates totais sob controle do Serviço de Inspeção Federal (SIF).

Os pesos a compor a média ponderada dos preços são, uma média ponderada mensal dos últimos três anos da quantidade de abates sob SIF de cada região, com pesos maiores para os anos mais recentes. Dessa forma, gera-se um painel mensal de ponderação, que permite captar a sazonalidade da atividade. Através dessa ponderação, obtêm-se o preço a vista ponderado no Estado de São Paulo. Finalmente, esse preço é convertido em dólares americanos pela taxa de câmbio de fechamento diário de venda, obtendo-se assim, o Indicador de Preços $\mathrm{BM} \& \mathrm{~F} / \mathrm{BOI} / \mathrm{ESALQ}$.

\subsection{Contrato futuro de soja no Brasil}

Em outubro de 1995 o contrato cambial de soja passou a poder ser liquidado financeiramente e a entrega física, como no caso da commodity boi gordo, só é permitida com o pleno consentimento das partes envolvidas.

O objeto de negociação do contrato é a soja em grão a granel, do tipo exportação, no padrão Concex, com até $14 \%$ de umidade; base de $1 \%$, não ultrapassando o máximo de $2 \%$ de impureza; máximo de $8 \%$ de grãos avariados, esses com até $5 \%$ de ardidos; máximo de $10 \%$ de grãos verdes e de $30 \%$ de grãos quebrados, cotada em reais por saca de $60 \mathrm{~kg}$. $\mathrm{O}$ tamanho do contrato equivale a 27 toneladas métricas ou 450 sacas de $60 \mathrm{~kg}$. Os meses de vencimento são março, 
maio, julho, setembro e novembro, e a partir de 27 de maio de 1996, fevereiro também foi incorporado como mês de vencimento. A data de liquidação do contrato é o último dia útil do mês de vencimento ( ver apêndice 2).

O indicador de preços utilizado para a liquidação dos contratos, até setembro de 1997, foi o Preço Nacional da Soja - PNS, elaborado pela Fundação Instituto de Pesquisas Econômicas - FIPE, a partir de um convênio assinado com a BM\&F e a Agência Estado. O PNS é uma média geométrica ponderada pelos diversos pesos atribuídos a cada região, em reais por saca de $60 \mathrm{~kg}$, das cotações no atacado, registradas nas principais regiões produtoras, excluída de quaisquer tributos incidentes e para pagamento imediato:

$$
\begin{aligned}
& P_{t}^{i .}=\prod_{k=1}^{m}\left(P_{t}^{i k}\right)^{1 / m} \\
& P N S_{t}=\prod_{i=1}^{r}\left(P_{t}^{i}\right)^{w_{t}}
\end{aligned}
$$

onde: $\mathrm{P}_{\mathrm{t}}^{\mathrm{i} .}=$ preço médio observado no dia $\mathrm{t}$, na região $\mathrm{i} ; \mathrm{m}=$ número de cotações observadas no dia $\mathrm{t}$, na região $\mathrm{i} ; \mathrm{P}_{\mathrm{t}}^{\mathrm{ik}}=$ preço fornecido pelo informante $\mathrm{k}$, na região $\mathrm{i}$, no dia $\mathrm{t} ; \mathrm{r}=$ número de regiões; $\mathrm{e}, \mathrm{w}_{\mathrm{i}}=$ peso atribuído à região $\mathrm{i}$.

Os pesos são tomados com base na participação de cada região onde foram feitas as cotações dos preços sobre a produção nacional de soja - safra 1993/94 (Tabela 1). Posteriormente o PNS é convertido para dólares americanos, pela taxa de câmbio comercial, preço de venda. Essa metodologia vigorou até os 
contratos com vencimento em setembro de 1997, nos subsequentes, passou-se a considerar a média móvel da participação de cada Estado nas três últimas safras.

A partir de setembro de 1997 o indicador utilizado nas liquidações dos contratos futuros de soja passou a ser o Indicador do Preço da Soja (IPS) elaborado pela CEPEA/FEALQ/ESALQ/USP. O IPS/ESALQ/BM\&F é uma média geométrica ponderada dos preços observados no Estado do Paraná para transações no mercado de lotes (atacado, disponível) entre vendedores (produtores/cooperativas) e compradores (indústrias/exportadores).

Tabela 1 - Pesos regionais utilizados no cálculo do Preço Nacional da Soja FIPE/BM\&F

\begin{tabular}{lc}
\hline Região & Peso $\left(\mathrm{w}_{\mathrm{i}}\right)$ \\
\hline Concórdia (SC) & 2,46 \\
Dourados (MS) & 10,78 \\
Maringá (PR) & 23,54 \\
Mogiana (SP) & 3,73 \\
Passo Fundo (RS) & 25,14 \\
Rondonópolis (MT) & 21,95 \\
Rio Verde (GO) & 10,54 \\
Sorocabana (SP) & 1,86 \\
\hline Total & 100,00
\end{tabular}

Fonte: Bueno (1995) e Frick (1996)

Na construção do indicador, o Estado do Paraná foi dividido em 5 regiões: Porto de Paranaguá, Ponta Grossa, Sudoeste, Oeste e Norte. Em cada uma dessas regiões, é consultada diariamente uma amostra representativa de 
participantes do mercado (compradores, vendedores e corretores) para coleta dos preços que comporão o indicador.

O cálculo do indicador é feito em duas etapas, descritas a seguir:

$1^{\mathbf{a}}$ etapa - Cálculo da média da região: serão consultadas as empresas compradoras e vendedoras e demais informantes em cada região e, posteriormente, calculada a média aritmética simples dos preços pagos pela indústria, obtendo-se um preço médio pago por região. $\mathrm{O}$ preço médio da região i será calculado por:

$$
P_{t}^{i}=\frac{1}{n} \sum_{i=1}^{n}\left(P_{t}^{i}\right)
$$

onde $P_{t}^{i}=$ preços da região $\mathbf{i}$ observados no dia $\mathbf{t}$ e, $\mathbf{n}=$ número de cotações observadas no dia $\mathbf{t}$.

$2^{\underline{a}}$ etapa - Cálculo da média do Estado: para qualquer dia t, o Índice de Preço Pago pela soja será calculado por:

$$
I P S_{t}=\prod_{i=1}^{n}\left(P_{t}^{i}\right)^{w i}
$$

sendo $w_{i}=$ ponderação da região $\mathbf{i}$, considerando-se as participações relativas das regiões na capacidade estática total de esmagamento do Estado do Paraná no ano imediatamente anterior, conforme mostrado na Tabela 2. Essas participações serão atualizadas anualmente. 
Tabela 2 - Ponderações regionais para o indicador de preços da soja ESALQ/BM\&F, 1997.

\section{REGIĀO}

PONDERAÇÃO (\%)

Porto de Paranaguá

19,13

Ponta Grossa

Norte

Oeste

9,73

Sudoeste

10,93

Total

100,00

Fonte: CEPEA/ESALQ/USP

\subsection{Trabalhos empíricos relacionados à liquidação financeira}

Os trabalhos empíricos que estudaram os contratos futuros com o mecanismo de liquidação financeira se enquadram, basicamente, em duas categorias, aqueles que usaram análise de simulação para investigar os impactos potenciais de mudança da entrega física para liquidação financeira, e os que analisaram a performance dos contratos após a introdução da liquidação financeira. Nesses trabalhos, o centro das investigações, se baseia, quase que exclusivamente, nos níveis da base, no risco ou previsibilidade da base, e sobre mudanças nas taxas ótimas de hedge.

O primeiro estudo usando simulação foi o de Cohen \& Gorham (1985). Nesse, a liquidação financeira para quatorze mercados foi avaliada utilizando dados semanais da commodity boi magro no período de 1980 a 1983. Eles concentraram a pesquisa no aumento dos custos de entrega associados com a 
entrega fisica, resultando em uma faixa maior de preços em que negociadores não poderiam obter lucro na arbitragem, e consequentemente, o risco da base aumenta.

Utilizando dados semanais para 1987, Paul (1987) calculou a correlação dos preços físico e futuro e simulou um indicador entre vários mercados e classes de gado, onde concluiu que o comportamento da base provavelmente melhoraria com a liquidação financeira.

$\mathrm{O}$ risco de hedging com liquidação financeira para o boi magro da CME, usando dados semanais para Arkansas de 1977 a 1986, foi simulado por Elam (1988). A abordagem utilizada pelo autor na determinação da razão ótima e da eficiência de hedging, difere levemente da de Cohen \& Gorham (1985). Os resultados desse trabalho evidenciaram que o risco de hedging diminuiria com a liquidação financeira, contudo, essa variação seria menor ou maior dependendo da classe da commodity.

O objetivo do trabalho de Schroeder \& Mintert (1988) foi examinar se a mudança da liquidação por entrega física para a liquidação financeira no contrato futuro do boi magro impactou o risco de hedging para garrotes e novilhas (cross hedging $^{8}$ ). A taxa de hedge e os riscos de hedging entre os contratos liquidados por entrega física e financeiramente, através de um indicador simulado, são comparados usando preços do boi de 1977 a 1987 em quatro mercados individuais nos EUA. Os resultados encontrados são similares aos de Elam

\footnotetext{
${ }^{8}$ Quando o hedging é feito para mercadorias com características diferentes daquelas especificadas no contrato.
} 
(1988), em que os riscos de hedging são geralmente, mas nem sempre, menores com a liquidação financeira do que sob as especificações da entrega física.

A introdução da liquidação financeira como uma forma de reduzir a variabilidade da base no contrato futuro, principalmente para a commodity novilhas, foi sugerido por Kenyon (1988), que estudou o mercado de boi na Virgínia (EUA) de 1986 a 1987. Esse trabalho, por ter sido desenvolvido em um período onde o mecanismo de liquidação financeira já tinha sido implementado (setembro de 1986 - CME), foi um dos primeiros a utilizar o indicador realmente empregado na liquidação e proceder a uma análise de eficiência de hedging do tipo antes e depois.

Kahl et al. (1989) utilizaram uma série de preços diários de 1980 a 1986 da commodity boi magro, para avaliar comparativamente o comportamento da base simulada para a liquidação financeira e para a base histórica. A análise abrangeu oito mercados de boi nos EUA e sete tipos de indicadores potenciais para a liquidação financeira. Como resultado, foi obtido somente um indicador simulado para a liquidação financeira, o Cattle-Fax Six State Index, que consistentemente reduziu a variabilidade da base. Nesse, os autores tentaram, também, mensurar o potencial para a manipulação do indicador utilizado na liquidação, onde consideraram como principal determinante da manipulação, a estrutura do mercado e o grau de competição entre as firmas compradoras e vendedoras.

A comparação de um contrato de entrega convencional com duas classes entregáveis (trigo duro vermelho e trigo mole vermelho) e um contrato com liquidação financeira, onde o indicador é uma média ponderada dos preços 
físicos das duas classes, foi desenvolvido por Lien (1989). Nesse trabalho, são assumidos dois períodos, o período presente e o da data comum de vencimento dos contratos futuros. É feita a suposição de que os dois contratos são exclusivistas um do outro, além do que, a comparação é baseada na expectativa de utilidade máxima obtida por cada contrato. Os resultados indicaram que $o$ contrato com liquidação financeira gera uma menor variância do preço futuro e o hedger será mais ativo em ambos os mercados, físico e futuro, quando usada a liquidação financeira em vez do mecanismo de entrega física. Por outro lado, as comparações das posições física e futura, dados os dois contratos hipotéticos, depende dos seguintes fatores: o custo de estocagem, o coeficiente de aversão ao risco, a correlação entre o preço físico, e os pesos empregados no contrato com liquidação financeira. A partir de tais inferências, o autor sugere que ao se assumir pequenos custos de armazenagem, grandes coeficientes de aversão ao risco, alta correlação dos preços, e simetria nos pesos, há uma grande contribuição para se ampliar os volumes de transações no caso dos contratos com liquidação financeira.

Rich et al. (1990) utilizaram dados referentes a dois anos pré e pós liquidação financeira em vinte e sete mercados de boi gordo para os EUA. Os resultados, em geral indicaram que através da liquidação financeira a variabilidade da base diminuiu.

A composição dos negociadores de boi magro com contrato e volume aberto, foi pesquisada por Rowsell \& Purcell (1990). Usando em torno de três anos de dados mensais pré e pós liquidação financeira, eles evidenciaram que a variabilidade da base decresce após a implantação da liquidação financeira. Contudo, eles preveniram que a eficiência do processo de descoberta de preço 
para mercados separados temporariamente (contratos distantes) seria prejudicada com o início do funcionamento dos contratos com liquidação financeira.

A base para lotes individuais de boi magro antes e depois da implantação do mecanismo de liquidação financeira em 16 mercados da Virgínia (EUA), foi estudada por Kenyon et al. (1991), onde dois conjuntos diferentes de dados foram utilizados. O primeiro consistiu das médias semanais de preços físicos e futuros para um número igual de semanas antes e depois da liquidação financeira usados na determinação da variância da base. Os períodos analisados foram de setembro de 1986 a abril de 1989 (138 semanas) e janeiro de 1984 a agosto de 1986, períodos pós e pré liquidação financeira, respectivamente. O segundo conjunto de dados consistiu de lotes individuais de preços de 1983 a 1988. Os resultados obtidos pelos autores mostraram que a variância da base não se reduziu com a implantação da liquidação financeira no contrato de boi magro e que a previsibilidade da base no vencimento do contrato não foi melhorada. A partir desses resultados, esses autores argumentaram que a eficiência de hedging depende da previsibilidade, quando o hedge é inicializado, para estimar o relacionamento entre os preços físico e futuro no vencimento do contrato. Se essa base de terminação não pode ser previsível, existirá uma diferença entre os preços recebidos esperado e líquido, reduzindo a eficiência de hedging. O importante são as variâncias e as covariâncias entre os preços físico e futuro. Esses autores foram os primeiros a cogitarem uma preocupação quanto às melhorias de desempenho na eficiência de hedging para o contrato futuro de boi magro utilizando o mecanismo de liquidação financeira.

Determinar como o lançamento da liquidação financeira tem influenciado as condições de hedging tanto no mercado individual quanto na 
indústria de engorda de boi em geral, foi o propósito do trabalho de Rich \& Leuthold (1993). Os dados analisados constituíram-se de preços médios semanais durante a semana de entrega, e incluem vinte e sete mercados físicos terminais localizados em vinte Estados diferentes nos EUA. Através de um ajustamento dos dados a um modelo de regressão, os autores puderam confirmar a redução da variabilidade da base na indústria quando se utiliza a liquidação financeira, porém em termos percentuais, a redução foi modesta. Ao analisarem os mercados individuais, constataram que, similar ao que ocorreu com a indústria, a diminuição da variabilidade foi mínima, e que associada a uma base claramente menor, essa é geralmente próxima de zero. Desse modo, a partir dos resultados obtidos, esses constataram que existe uma melhora inicial no comportamento da base, mas que essa mudança não é sustentável; e, de fato, piorou durante as observações mais recentes. Uma possível explanação para esses resultados, é que as diferenças espaciais e o volume da commodity fazem com que a arbitragem se torne difícil e cara, resultando em uma negociação na própria região, que pode não ser diretamente repassada para a área principal de produção de engorda de boi. Assim, os autores sugerem que a adoção da liquidação financeira tem melhorado a performance do contrato para alguns hedgers, porém não para todos, com os resultados diferindo de acordo com as informações utilizadas.

Kimle \& Hayenga (1994), simularam vários indicadores alternativos, de contrato futuro de suíno, para a liquidação financeira e analisaram seus efeitos sobre os níveis e variabilidades das bases para dezenove mercados físicos nos EUA. Foram utilizados preços diários do mercado terminal ${ }^{9}$ e leilões, de janeiro de 1985 a setembro de 1990. Os fatores usados na avaliação dos indicadores de liquidação financeira foram: a variação padrão do valor da base

\footnotetext{
${ }^{9}$ currais públicos onde é armazenado animais que se destinam ao abate, à venda ou ao transporte.
} 
resultante do mecanismo de liquidação, a capacidade de entendimento da construção do indicador por parte dos negociadores, e a susceptibilidade do indicador à manipulação. Os resultados evidenciaram que o risco de hedging utilizando o indicador foi geralmente menor do que o estimado usando a entrega física, além de ser relativamente consistente nos quatro mercados. Foi constatado, também, que a taxa ótima de hedge aumentaria, nesses mercados, de $10 \%$ com a entrega física para $15 \%$ utilizando a liquidação financeira. A constatação feita por esses autores, é que a integração dos preços físicos do suíno, geograficamente dispersos, é um fator importante na determinação do desempenho dos vários indicadores para o contrato futuro. $\mathrm{O}$ número de dias de mercado incluídos no indicador pode aumentar a proteção contra a manipulação, contudo, existe um custo associado a isto. Com relação ao número de localizações utilizadas na construção do indicador, a resposta é menos definitiva, sendo difícil determinar qual o número ideal de mercados que seria usado. Os autores sugerem, também, que a probabilidade de manipulação de preços de suínos em algum dos indicadores utilizados seria mínima com a construção de um indicador apropriado.

Os impactos dos termos de liquidação sobre a eficiência de hedging para os contratos futuros de milho e soja negociados na Chicago Board of Trade (CBOT), foram investigados por Chaherli \& Hauser (1995). Os resultados obtidos por esses autores indicaram que a eficiência de hedging quando medida individualmente em localizações sem entrega, responde às mudanças nos diferenciais de entrega, tão bem como as localizações com entrega. Contudo, como os resultados são agregados no espaço, as mudanças nas especificações de liquidação tendem a afetar o desempenho de hedging somente marginalmente. Assim, eles concluíram que a liquidação financeira provê um nível levemente 
mais alto de eficiência de hedging do que algum tipo de entrega física múltipla estudada. Quando os resultados da performance da liquidação financeira são avaliados para o conjunto total de localizações sem entrega, esses demonstraram não serem sensíveis aos esquemas de pesagem ou à composição do indicador. Paralelamente, os autores construíram um indicador onde as localizações são aleatoriamente tiradas de um conjunto de mercados terminais, com o propósito de inibir a manipulação sobre a liquidação financeira. A análise sugeriu que um indicador poderia prover uma boa medida do valor físico e ser de difícil manipulação.

Em fevereiro de 1997, começou a vigorar na CME, a nova especificação de liquidação de contratos futuros de suíno magro, que consiste da liquidação financeira como alternativa à liquidação por entrega física tradicional. $O$ indicador utilizado é baseado em um amplo conjunto de preços de suíno magro, eliminando o mercado terminal do processo de descoberta de preço. Usando esse indicador sobre um período de vinte meses como uma proxy para o preço futuro de suíno magro, Ditsch \& Leuthold (1996) comparam a eficiência de hedging dos contratos futuros de suíno com o potencial de hedging do contrato futuro de suíno magro em relação ao mercado físico de suíno, assim como para quatro classes de cortes de carnes. Os contratos futuros de barrigada congelada de suíno, também são examinados para o mercado físico de cames. Ambos, hedges de longo e curto prazo são simulados, usando a aproximação da variância mínima, que utiliza somente informações incondicionais e a abordagem de Myers-Thompsom ${ }^{10}$ que incorpora informações condicionais. Os resultados evidenciaram que o contrato futuro de suíno magro, liquidado financeiramente, teria um desempenho melhor que o contrato futuro de suíno ou o contrato futuro de barrigada congelada de

\footnotetext{
${ }^{10}$ maiores informações ver Myers e Thompson (1989).
} 
suíno tradicional como um instrumento para o mercado físico de suíno e lombo de Omaha. A evidência mais forte disto é sentida no hedging de curto prazo para o mercado físico de suíno. Para os outros três tipos de carnes, os contratos futuros não demonstraram uma clara vantagem de hedging.

O primeiro trabalho realizado no Brasil levando em consideração a liquidação financeira, é o de Lazzarini (1997). Nesse, o autor utilizando-se de séries temporais com dados diários para os períodos que compreendem a entrega física em vários locais (04/01/1993 a 20/12/1993), a entrega física em um único ponto - Araçatuba (27/05/1994 a 16/12/1994) e a liquidação financeira (16/12/1994 a 30/10/1996), analisa, entre outras coisas, o efeito de inovações no desenho contratual do boi gordo sobre a demanda por posições (número de contratos em aberto), evidenciando que tais inovações possivelmente acabaram por reduzir custos de transação ex-post aos participantes, principalmente com respeito aos procedimentos de liquidação do contrato, resultando em um aumento no número de posições.

A análise do impacto da introdução da liquidação financeira sobre o risco de base para os mercados brasileiros, foi desenvolvida por Rochelle (1997). O estudo consiste, basicamente, em avaliar o desempenho da base para a commodity boi gordo, onde são comparados os períodos pré e pós liquidação financeira. $\mathrm{O}$ risco de base foi representado pela variância e a análise foi feita para animais machos e fêmeas em nove regiões. Para verificar se e como a adoção da liquidação financeira afetou o risco de base na semana de vencimento do contrato, foram utilizados testes para igualdade de variâncias nos períodos anterior e posterior à sua utilização. Foi estimado um modelo de regressão do desvio padrão da base contra variáveis binárias para isolar o impacto da 
liquidação financeira sobre o risco de base e identificar se esse difere entre regiões e entre sexos. Os resultados sugerem que após a introdução da liquidação financeira o risco de base foi reduzido para machos e fêmeas em todas as regiões consideradas em 78,08\%. Pôde-se constatar também que o risco da base apresentou-se menor para machos, para as regiões que compõem o cálculo do Indicador Boi Gordo (IBG) e para os contratos com meses de vencimento na safra em relação às fêmeas, às demais regiões e aos contratos com vencimento na entressafra, respectivamente.

Deve-se observar que todos os estudos que utilizaram simulação, assumem que os preços futuros se comportarão identicamente tanto sobre entrega física quanto liquidação financeira. Contudo, os níveis da base média mudarão porque os contratos liquidados financeiramente representarão animais com preços diferentes daqueles contratos com liquidação física. Apesar disto, uma vez que a base estimada nesses estudos geralmente é calculada somente na semana do vencimento dos contrato e considerando que muitos hedgers liquidam suas posições antes do seu vencimento (mesmo sob liquidação financeira), Leuthold (1992) sugere que as análises utilizando a simulação são os melhores cenários, visto que a convergência pode não ocorrer até o último dia.

A conclusão básica, a que praticamente todos os trabalhos, que analisaram empiricamente a eficiência de hedging chegaram, é que a variabilidade da base reduz, em maior ou menor grau, com a implantação da liquidação financeira como mecanismo de liquidação dos contratos futuros. Contudo, a construção do indicador é o principal problema relacionado a essa variabilidade, assim um indicador representativo do mercado físico, com boa visibilidade, com 
potencial de credibilidade e não susceptível à manipulação é requerido para evitar os riscos e aumentar a previsibilidade da base. 


\section{MATERIAL E MÉTODOS}

A abordagem metodológica utilizada nesse trabalho é baseada no estudo feito por Chaherli \& Hauser (1995), que analisa a eficiência de hedging para o mercado de soja e milho nos EUA. A esse trabalho são acrescentadas determinadas peculiaridades, bem como são feitas adequações no sentido de ajuste do modelo ao que se propõe.

\subsection{Modelo de preços futuros com opção de localização}

A opção de entrega representa um importante papel na avaliação dos contratos futuros quando o contrato permite tal flexibilidade. A partir das colocações feitas por Margrabe (1978) e Johnson (1987), Boyle (1989) mostra que o preço futuro de um contrato que permite a entrega de vários bens de um conjunto de $\mathbf{n}$ bens, é igual ao valor de uma opção de compra sobre o menor valor dos $\mathbf{n}$ bens, com um preço de exercício zero. O modelo formal para preços futuros com uma opção de localização assume: (1) a existência de um mercado perfeito (sem atrito); (2) um conhecimento constante da taxa de juros $\mathbf{r}$, uma vez que os preços futuros são iguais aos preços correspondentes no futuro; (3) no vencimento do contrato, o vendedor entregará a commodity na localização mais barata; (4) não existe custo de transação; e, (5) os preços na localização de entrega aceitável são normalmente distribuídos. 
A notação convencionada, é a seguinte:

$\mathbf{t}$ : tempo corrente;

$\mathbf{T}$ : tempo para a expiração do contrato;

$\mathbf{L}_{\mathbf{i}}$ : localização $\mathbf{i}$ em que a entrega pode ser feita;

$\mathbf{P}_{i t}:$ preço corrente na localização de entrega $\mathbf{L}_{\mathbf{i}}$ em $\$ / @$ para $\mathbf{i}=1,2, \ldots, n$;

K : preço de exercício da Call e Put Européia em \$/@;

$F_{t}\left(P_{1}, P_{2}, \ldots, P_{n} ; T\right)=F_{t}$ : preço futuro no tempo $t$ de um contrato, permitindo aos vendedores entregarem em alguma das localizações $\mathbf{L}_{\mathbf{i}}$ 's;

$\mathbf{E C}_{\mathrm{t}}\left(\mathbf{P}_{1}, \mathbf{P}_{2}, \ldots, \mathbf{P}_{n} ; \mathrm{K} ; \mathbf{T}\right)=\mathbf{E C}_{\mathrm{t}}(\mathbf{K})$ : preço de uma opção de compra (Call) européia no tempo $\mathbf{t}$ sobre o menor preço dos $\mathbf{n}$ preços nas localizações de entrega incluídas no conjunto aceitável, com um preço de exercício $\mathbf{K}$ e data de expiração $(t+T)$. Na expiração, o valor da Call é $\operatorname{Max}\left\{\left[\operatorname{Min}\left(\left(P_{1}, P_{2}, \ldots, P_{n}\right)-K\right], 0\right\}\right.$; e $\mathbf{E P}_{\mathbf{t}}\left(\mathbf{P}_{1}, \mathbf{P}_{2}, \ldots, \mathbf{P}_{\mathbf{n}} ; \mathbf{K} ; \mathbf{t}+\mathbf{T}\right)=\mathbf{E P}_{\mathbf{t}}(\mathbf{K})$ : preço de uma opção de venda (Put) européia no tempo $\mathbf{t}$ sobre o menor preço dos $n$ preços na localização de entrega incluída no conjunto aceitável, com um preço de exercício $\mathbf{K}$ e data de expiração $(t+T)$. Na expiração, o valor da Put é $\operatorname{Max}\left\{\left[K-\operatorname{Min}\left(P_{1}, P_{2}, \ldots, P_{n}\right)\right], 0\right\}$.

A compra de um contrato futuro que possua como forma de liquidação a entrega física em uma única localização, pode ser reproduzido a partir da compra de uma Call e da venda de uma Put européias. Assumindo um risco neutro, o preço futuro é só o preço spot esperado no futuro. Essa estrutura de um único ponto de entrega precisa, contudo, ser generalizada quando o conjunto de possíveis localizações de entrega inclui mais de um mercado. No caso de $\mathbf{n}$ possíveis localizações de entregas, $\mathbf{o}$ valor $\mathbf{f}$ de um contrato futuro é igual à compra de uma Call sobre o menor preço de $\mathbf{n}$ bens mais a venda de uma Put sobre o menor preço de $\mathbf{n}$ bens, assim expresso: 
$f=E C_{t}\left(P_{1}, P_{2}, \ldots, P_{n} ; K ; t+T\right)-E P_{t}\left(P_{1}, P_{2}, \ldots, P_{n} ; K ; t+T\right)$

Margrabe (1978), Stulz (1982) e Johnson (1987) estenderam a relação de paridade entre Put - Call como sendo uma opção sobre o menor valor de $\mathbf{n}$ bens dando a seguinte expressão alternativa para a equação (1):

$f=E C_{t}\left(P_{1}, P_{2}, \ldots, P_{n} ; 0 ; t+T\right)-K^{-r T}$

Quando o contrato futuro é iniciado, o seu valor é igual a zero, fazendo com que o preço futuro seja igual ao valor do preço de exercício da opção de compra:

$f=0==K=F_{t}\left(P_{1}, P_{2}, \ldots, P_{n} ; t+T\right)$

A partir da combinação das equações (2) e (3) obtêm-se uma expressão para os preços futuros, quando uma opção de localização de entrega é incluída na especificação do contrato, mais fácil de ser trabalhada:

$F_{t}\left(P_{1}, P_{2}, \ldots, P_{n} ; t+T\right)=e^{r T} E C_{t}\left(P_{1}, P_{2}, \ldots, P_{n} ; t+T\right)$

Se o valor de $\mathrm{EC}_{\mathrm{t}}(\mathrm{K}=0)$ puder ser encontrado, então, o valor do preço futuro o seguirá diretamente. Johnson (1987) e vários outros derivaram uma expressão geral para $\mathrm{EC}_{\mathrm{t}}\left(\mathrm{P}_{1}, \mathrm{P}_{2}, \ldots, \mathrm{P}_{n} ; \mathrm{K} ; \mathrm{t}+\mathrm{T}\right)$, o valor de uma opção de compra sobre o mínimo de $\mathrm{n}$ bens. O preço de exercício tendendo a zero, produz a seguinte expressão para $\mathrm{EC}_{\mathrm{t}}(\mathrm{K}=0)$ :

$E C_{t}(K=0)=P_{1} N_{n}\left(d_{12}\left(P_{1}, P_{2}, \sigma_{12}^{2}\right), \ldots, d_{1 n}\left(P_{1}, P_{n}, \sigma_{1 n}^{2}\right),-\rho_{112},-\rho_{113}, \ldots, \rho_{123}, \ldots\right)$ 


$$
\begin{aligned}
& +P_{2} N_{n}\left(d_{21}\left(P_{2}, P_{1}, \sigma_{21}^{2}\right), \ldots, d_{2 n}\left(P_{2}, P_{n}, \sigma_{2 n}^{2}\right),-\rho_{221},-\rho_{223}, \ldots, \rho_{213}, \ldots\right) \\
& +P_{n} N_{n}\left(d_{n 1}\left(P_{n}, P_{1}, \sigma_{n 1}^{2}\right), \ldots, d_{n n-1}\left(P_{n}, P_{n-1}, \sigma_{n-1 n}^{2}\right),-\rho_{m n l},-\rho_{n n 2}, \ldots, \rho_{n 12}, \ldots\right)
\end{aligned}
$$

onde

$$
\mathrm{d}_{\mathrm{ij}}=\frac{\ln \frac{\mathrm{P}_{\mathrm{j}}}{\mathrm{P}_{\mathrm{i}}}-1 / 2 \sigma_{\mathrm{ij}}^{2} \mathrm{~T}}{\sigma_{\mathrm{ij}} \sqrt{\mathrm{T}}}
$$

$\rho_{i \mathrm{ij}}=\frac{\sigma_{\mathrm{i}}-\rho_{\mathrm{ij}} \sigma_{\mathrm{j}}}{\sigma_{\mathrm{ij}}} \quad$ para $\mathrm{i} \neq \mathrm{j} ; \mathrm{i}, \mathrm{j}=1,2, \ldots, \mathrm{n}$

$\rho_{\mathrm{ijk}}=\frac{\sigma_{\mathrm{i}}^{2}-\rho_{\mathrm{ij}} \sigma_{\mathrm{i}} \sigma_{\mathrm{j}}-\rho_{\mathrm{ik}} \sigma_{\mathrm{i}} \sigma_{\mathrm{k}}+\rho_{\mathrm{jk}} \sigma_{\mathrm{j}} \sigma_{\mathrm{k}}}{\sigma_{\mathrm{ij}} \sigma_{\mathrm{ik}}} \quad$ para $\mathrm{i} \neq \mathrm{j} \neq \mathrm{k} ; \quad \mathrm{i}, \mathrm{j}, \mathrm{k}=1,2, \ldots, \mathrm{n}$

$\sigma_{\mathrm{i}}^{2}=\operatorname{Var}\left(\Delta \ln \mathbf{P}_{\mathrm{i}}\right)$

$\rho_{\mathrm{ij}}=\operatorname{Corr}\left(\Delta \ln \mathrm{P}_{\mathrm{i}}, \Delta \ln \mathrm{P}_{\mathrm{j}}\right)$

$\sigma_{\mathrm{ij}}^{2}=\operatorname{Var}\left(\Delta \ln \frac{P_{\mathrm{i}}}{P_{\mathrm{j}}}\right)=\sigma_{\mathrm{i}}^{2}-2 \rho_{\mathrm{ij}} \sigma_{\mathrm{i}} \sigma_{\mathrm{j}}+\sigma_{\mathrm{j}}^{2}$

e $\mathrm{N}_{\mathrm{n}}$ (.) é a distribuição normal cumulativa n-dimensional com os argumentos definidos acima. $\mathrm{O}$ valor da opção é, de fato, uma média ponderada dos preços nas localizações dentro do conjunto de entregas possíveis. Esses pesos podem ser interpretados como a probabilidade sem risco de que uma localização particular será a mais barata, dado não somente o nível de preços, mas também o grau de correlação entre eles. Esses preços carregam toda a informação necessária para 
avaliar a probabilidade de uma localização particular ser a mais barata, na existência de um padrão de correlação entre todas as localizações de entrega $\mathbf{L}_{\mathbf{i}}$. Isso mostra intuitivamente o uso de uma distribuição conjunta para os preços no conjunto de localizações entregáveis. A determinação das probabilidades referentes a cada localização é possível a partir da utilização de um artifício matemático denominado "aproximação de Cholesky". De acordo com Rencher (1995) esse método consiste em fragmentar a matriz de correlação dos preços anteriormente determinada e utilizá-la na correção dos dados originais (detalhes no apêndice 3).

No caso de quatro localizações de entregas possíveis, como é o caso desse estudo, o valor estimado do preço futuro é:

$$
\begin{aligned}
& F_{t}=e^{r T} \sum_{i=1}^{4} P_{i t} N_{4}\left(d_{i j} ; d_{i k} ; d_{i z} ; \rho_{i}\right) \quad i \neq j \neq k \neq z ; \quad i, j, k, z=1,2,3,4 \\
& N_{4}\left(d_{I J} ; d_{i k} ; d_{i z} ; \rho_{i}\right)=\int_{-\infty}^{+\infty} \int_{-\infty}^{d_{y}} \int_{-\infty} \int_{-\infty} \int_{-\infty} f(r, s, x, y) d_{r} d_{s} d_{x} d_{y} \\
& \rho_{i}=\left[\begin{array}{cccc}
1 & -\rho_{i j} & -\rho_{i i k} & -\rho_{i i z} \\
-\rho_{i j} & 1 & \rho_{i j k} & \rho_{i j z} \\
-\rho_{i i k} & \rho_{i j k} & 1 & \rho_{i k z} \\
-\rho_{i z} & \rho_{i j z} & \rho_{i k z} & 1
\end{array}\right]
\end{aligned}
$$

Os argumentos da distribuição cumulativa com quatro variáveis, são definidos com a opção de preço, na fórmula (5). Esse método pode ser extrapolado para contratos baseados na liquidação financeira, por exemplo, supondo um contrato com múltiplas localizações utilizadas na construção do indicador, $\mathbf{o} \mathbf{F}_{\mathbf{t}}$ pode ser interpretado como o preço comum para a liquidação (PCL) dos contratos ponderado pela probabilidade de que o preço de cada região será o mais barato. Isso ocorre devido ao fato desse preço ser determinado na 
semana de vencimento do contrato, representando assim um indicador físico, para o qual o preço futuro irá convergir. Como mostra a equação (6), a estimação do PCL envolve o cálculo da integral com quatro dimensões para a distribuição normal cumulativa multivariada. A distribuição normal tetra variável captura o fato de que os preços nas localizações entregáveis são conjuntamente determinados. Para a localização\#1, por exemplo, ser a mais barata, sobre a faixa total de preços tomados por $\mathbf{P}_{1}$, requer que $\mathbf{P}_{\mathbf{1}}$ seja menor que $\mathbf{P}_{\mathbf{2}}$ (determinado acima do limite de integração $\mathbf{d}_{12}$ ), menor que $\mathbf{P}_{\mathbf{3}}$ (determinado acima do limite de integração $\mathbf{d}_{13}$ ), e menor que $\mathbf{P}_{\mathbf{4}}$ (determinado acima do limite de integração $\mathbf{d}_{14}$ ), simultaneamente. Assim, o uso da metodologia, que simula preços comuns para a liquidação de contratos, relacionada à probabilidade de que cada localização será a mais barata, está associado à sugestão feita por alguns autores, de que o preço futuro de um contrato, com entrega física em múltiplas localizações, é representado pelo valor da commodity entregável da localização mais barata. Dentre os autores que fizeram tal referência estão: Jones (1982), Garbade \& Silber (1983a), Kahl et al. (1989), Rich \& Leuthold (1993), Chaherli \& Hauser (1995), entre outros. Pode-se expandir as considerações feitas por esses autores, inferindo que similar ao que acontece sob a especificação de entrega física, quando se trabalha com liquidação financeira, o preço futuro também irá acompanhar mais proximamente a região, participante da construção do indicador, com preço mais barato.

O valor da commodity no mercado físico varia de acordo com sua classe e localização. Contudo, no caso dos mercados futuros, esses podem diversificar em um determinado número de caminhos, cada um requerendo uma abordagem diferente para projetar o contrato. Garbade \& Silber (1983b) 
examinam três tipos de abordagens que consideram as classes das commodities e as localizações de entrega com determinantes na ocorrência de squeezes.

Uma primeira abordagem para especificar um contrato futuro, é definir a entrega aceitável em termos de um pequeno conjunto de características em uma única localização. Essa especificação dá ao comprador total certeza sobre o que ele irá receber, mas expande a possibilidade de uma multiplicidade de estreitamentos definidos nos contratos. Esse argumento possui duas desvantagens principais. Primeiro, ela fragmenta a negociação sobre um grande número de contratos e portanto reduz o total de liquidez no mercado (ver Garbade \& Silber, 1979). A segunda, é que o estreitamento da especificação do contrato aumenta a probabilidade de squeezes.

Uma segunda abordagem para projetar um contrato futuro é especificar a entrega aceitável em termos de uma ampla faixa de classes de commodities e localizações de entrega, sem estipular qualquer preço de ajustamento. A priori, um contrato futuro permitindo a entrega de várias classes em um número determinado de localizações parece resolver o problema de squeezes enquanto aumenta a liquidez dos contratos. Contudo, o preço de tal contrato é mais estritamente relacionado às classes entregáveis mais baratas. Por exemplo, supondo duas classes entregáveis (A e B) num contrato futuro e que o preço de $\mathbf{A}$ no mercado físico é, em média, $10 \%$ maior do que o de $\mathbf{B}$. Uma vez que A é normalmente considerado um prêmio, os participantes do mercado não esperarão entregá-la, e o preço do contrato futuro dependerá, primariamente, dos preços físicos e futuros da classe B. O preço de A poderia influenciar a negociação futura significativamente se mudanças na oferta e demanda eliminassem o prêmio normal de $10 \%$. Assim, essas características podem não 
aumentar compensatoriamente a liquidez dos contratos, como podem, talvez, realçar os mais severos squeezes.

Uma terceira abordagem, é permitir entregar no preço contratado de uma classe padronizada em uma localização específica, mas também consentir entregar classes não padronizadas (em localizações alternativas) com descontos e prêmios sobre o preço contratado. Assim, a opção de entrega desigual possui duas importantes implicações: um squeeze na classe padronizada será amenizado antes de tornar-se severo e o preço futuro de um contrato, na maioria das vezes, irá refletir a classe não padronizada.

A estrutura de prêmios e descontos em entregas desiguais sugere a existência de dois tipos de regras de preços desiguais, como apresentado em Garbade e Silber (1983b): (1) sistema de equivalência, que especifica prêmios e descontos baseados na quantidade de características particulares de um lote entregável relativo a um padronizado; e, (2) sistema de penalidade, que especifica prêmios e descontos sem referência a qualquer característica básica.

O sistema de equivalência é usado quando uma característica básica da commodity pode ser isolada através de um processo de extração tecnológica, por exemplo, a classificação do ouro que é feita através de sua pureza. Isto facilita a concordância na fixação de preços, entre compradores e vendedores, para classes diferentes.

Um sistema de penalidade é usado quando a fixação de preço é difícil e quando os participantes do mercado têm preferência por uma classe específica. Nesse caso, um contrato futuro pode permitir a entrega de lotes não 
padronizados com penalidade. Compradores normalmente esperariam receber lotes de acordo com os padrões fixados nos contratos, e em circunstâncias anormais, vendedores estariam pagando uma penalidade àqueles como compensação por entregarem classes fora dos padrões estipulados.

Vários contratos futuros permitem preços desiguais como uma função da localização de entrega. A entrega é permitida no preço contratado, no ponto especificado (comumente referido como a localização equivalente), por exemplo localização A. Os termos para entregas desiguais (isto é, em outra localização) são descritos, como um vendedor pretendendo entregar uma commodity especificada no contrato, em uma localização alternativa (localização B), deve receber o preço do contrato menos um desconto, se o preço de entrega em A for maior do que em B. Se for o contrário, o vendedor receberá o preço do contrato mais um prêmio. Assim, com a utilização de prêmios ou descontos, será necessário uma ligeira modificação no modelo de preços futuros descritos pela equação (1). Nesse caso, $\mathrm{P}_{\text {it }}$ é substituído por $\mathrm{P}^{\prime}{ }_{\text {it }}$ definido como:

$\mathrm{P}_{\text {it }}^{\prime}=\mathrm{P}_{\mathrm{it}}+\delta_{\mathrm{i}}$

onde $\delta_{\mathrm{i}}=\mathrm{P}_{\mathrm{k}}-\mathrm{P}_{\mathrm{i}} ;$ se: $\left\{\begin{array}{l}\delta_{\mathrm{i}}<0, \delta_{\mathrm{i}}=\text { prêmio } \\ \delta_{\mathrm{i}}>0, \delta_{\mathrm{i}}=\text { desconto; }, \\ \delta_{\mathrm{i}}=0, \text { (preço igual). }\end{array}\right.$

Quase todos os contratos futuros existentes previnem-se contra preços desiguais baseados em diferenças espaciais, contendo termos de entrega especificados (prêmios e descontos constantes). Contudo, quando as diferenças dos preços comerciais estão sujeitas às mudanças estruturais, o ajustamento constante pode não refletir as intenções existentes quando os termos foram 
descritos. Uma alternativa para prêmios/descontos constantes é permitir a variação da especificação de desconto sobre o tempo, como feito no contrato de algodão negociado na New York Cotton Exchange. A troca pode ser feita com ajustamentos regulares, dependendo do comportamento das diferenças do preço a vista antes da expiração de cada contrato. Para avaliar o ajustamento no desconto, $P_{i t}$ na equação (1) é substituído por $P{ }{ }_{i t}$, definido como:

$\mathrm{P}^{\prime \prime}=\mathrm{P}_{\mathrm{it}}+\delta_{\mathrm{it}} ; \delta_{i t}=\frac{1}{t^{*}} \sum_{j=1}^{t}\left(P_{k, t-j}-P_{i, t-j}\right) \quad \mathrm{i}=1,2, \ldots, \mathrm{I}$.

onde: $\delta_{i t}$ é o ajustamento da média móvel; $\mathrm{P}_{\mathrm{K}, \mathrm{t} \text { j }}$ é o último preço na localização estipulada $\mathrm{L}_{\mathrm{K}} \in \Phi_{\mathrm{I}} ; \mathrm{P}_{\mathrm{i}, \mathrm{t}-\mathrm{j}}$ é o último preço na localização não estipulada $\mathrm{L}_{\mathrm{K}} \in \Phi_{\mathrm{I}}$; $\left[t^{*}\right.$ - t] é a medida do horizonte da média móvel; e, $\Phi_{I}$ é o conjunto de localizações de entrega $L_{i}$.

Similarmente ao que ocorre com a entrega fisica, esse procedimento, no caso da liquidação financeira, visa diminuir as diferenças entre os preços das regiões que compõem o preço comum de liquidação (PCL).

\subsection{Construção de um indicador}

Vários esquemas de pesos têm sido usados e sugeridos quando são designados termos para liquidar contratos financeiramente. A abordagem utilizada nesse trabalho reflete a informação derivada da simulação de preços comuns de liquidação, através do uso das probabilidades de entrega mais barata (probabilidades-EMB). Alguns dos fundamentos do mercado são refletidos não 
somente através dos preços nas localizações de entrega, mas também através da probabilidade da localização tornar-se a mais barata no término do contrato. Como sugerido por Hauser et al. (1992), as probabilidades-EMB médias considerando um determinado período de tempo podem ser usadas como peso no indicador de preço.

Esse tipo de indicador tem uma das características desejáveis, que um indicador com pesos constantes não necessariamente teria: a habilidade para refletir a informação relevante tirada do dinamismo existente nos mercados spot. Para ilustrar tal esquema de ponderação, considera-se o conjunto de localizações entregáveis, contendo 4 mercados: mercado \#1, mercado \#2, mercado \#3 e mercado \#4. A equação (1) pode ser rescrita como:

$F_{t}=e^{r T}\left[P_{i t} W_{1 t}+P_{2 t} W_{2 t}+P_{3 t} W_{3 t}+P_{4 t} W_{4 t}\right]$

onde: $\mathrm{W}_{\mathrm{it}}=\mathrm{N}_{4}\left(\mathrm{~d}_{\mathrm{ij}}, \rho_{\mathrm{i}}\right) \quad ; \quad \mathrm{i}=1,2,3,4$.

sendo que cada preço é ponderado com a probabilidade de que a commodity na respectiva localização será a mais barata. $\mathrm{N}_{4}$ (.) é a distribuição normal acumulada com quatro variáveis cujos argumentos $d_{i j}$ (vetor de limite superior) e $\rho_{i}$ (matriz de correlação), são definidos na equação (5). Calcula-se as médias das probabilidades determinadas na equação (5), por um período estipulado de tempo, para dar uma probabilidade-EMB média para cada respectivo preço. A partir daí, define-se o IEMB (Indicador ponderado pela probabilidade mais barata) como um indicador do preço físico:

$$
I_{t}^{\mathrm{EMB}}=\mathrm{e}^{\mathrm{rT}}\left[\mathrm{P}_{1 \mathrm{t}} \widehat{\mathrm{W}}_{1}+\mathrm{P}_{2 \mathrm{t}} \widehat{\mathrm{W}}_{2}+\mathrm{P}_{3 \mathrm{t}} \hat{\mathrm{W}}_{3}+\mathrm{P}_{4 \mathrm{t}} \widehat{\mathrm{W}}_{4}\right]
$$


sendo: $\widehat{W}_{\mathrm{i}}=\frac{1}{\tau} \sum_{\mathrm{k}=0}^{\tau} \mathrm{W}_{\mathrm{ik}}$

onde $[0, \tau]$ é o intervalo de tempo sobre o qual, as médias das probabilidadesEMB são tiradas. Esse indicador difere dos indicadores que têm sido usados no passado em liquidação financeira, no sentido de que usa informações vindas de um sistema de entrega física simulado, mas que serve como um preço de liquidação na expiração do contrato. Daqui por diante, esse tipo de indicador será conhecido como indicador-EMB (IEMB) ponderado para refletir a junção entre as probabilidades-EMB e os pesos usados no indicador ao longo do tempo.

\subsection{Avaliação da performance de hedging}

A questão de hedge em mercados futuros é abordada principalmente através da teoria tradicional, da teoria de Working, e da teoria do portfolio (Ederington, 1979). A teoria tradicional propõe que a venda ou a compra no mercado futuro, com o intuito de redução do risco, seja de igual montante à quantidade negociada no mercado físico.

A teoria de Working sugere o uso do hedge denominado "discreto", onde o agente, baseado em mudanças previsíveis na base, isto é, considerando alterações favoráveis ou desfavoráveis, realiza $100 \%$ ou $0 \%$ de hedge, respectivamente.

A teoria do portfolio pode ser usada para medir a eficiência de hedge, para isto compara-se o risco da posição hedgeada que minimiza o risco em 
relação à posição não hedgeada. Na formulação desses modelos, os preços no mercado físico são tomados como variáveis dependentes, enquanto os preços no mercado futuro como independentes. Essa relação de causalidade é abordada em Purcell (1991). Esse mesmo autor coloca que ambos os mercados (físico/futuro) reagem ao mesmo tipo de informação, sendo que o tempo de reação depende de suas próprias capacidades. O mercado futuro por ser mais concentrado, onde as pessoas são mais preparadas e a freqüência de operações é maior, geralmente, é mais eficiente e mais rápido na assimilação das informações. Por isso, tem-se a impressão de que o mercado futuro "causa" o mercado físico.

A efíciência de hedging é medida, de acordo com Ederington (1979), como a redução percentual na variância de retornos alcançados por uma posição com hedge em oposição a uma sem hedge. Essa medida de eficiência assume uma estratégia de hedging para minimizar a variância de preço. A medida típica de eficiência é usada para analisar a efíciência de decisões de hedging feitas por indivíduos para cada especificação de liquidação discutida nas seções anteriores. Fazendo $\pi$ ser o lucro ou a perda de um hedge, $h$ ser a fração da posição a vista com hedge e $\mathbf{h}^{*}$ ser a proporção de hedge para minimização de risco, a medida de eficiência de hedging (HE) é definida como a diferença entre a variância da posição sem hedge, $\operatorname{Var}\left(\pi_{\mathrm{h}}=0\right)$ e a variância da posição assegurada, $\operatorname{Var}\left(\pi_{\mathrm{h}^{*}}\right)$, dividido pela variância da posição sem hedge:

$\mathrm{HE}=\frac{\operatorname{Var} \pi_{\mathrm{h}=0}-\operatorname{Var} \pi_{\mathrm{h}^{*}}}{\operatorname{Var} \pi_{\mathrm{h}=0}}=\frac{\sigma_{\mathrm{pf}}^{2}}{\sigma_{\mathrm{f}}^{2} \sigma_{\mathrm{p}}^{2}}=\mathrm{R}^{2}$

$\sigma_{p f}^{2}=\operatorname{Cov}\left(\Delta P_{t}, \Delta F_{k, t}\right) ; \sigma_{f}^{2}=\operatorname{Var}\left(\Delta F_{k, t}\right) ; \sigma_{p}^{2}=\operatorname{Var}\left(\Delta P_{t}\right)$ 
onde $\mathbf{R}^{2}$ é o coeficiente de deteminação da regressão dos Mínimos Quadrados Ordinários nos preços a vista sobre os preços dos contratos futuros expirando no tempo T:

$$
P_{i t}=\alpha_{i j}+\beta_{i j} F_{j t}+\varepsilon_{i j t}
$$

sendo $\mathbf{F}$ o preço futuro definido no mercado e, também, o preço comum de liquidação baseado em um dos processos definidos anteriormente; e, $\mathbf{P}_{\mathbf{i}} \mathbf{o}$ preço a vista na localização $\mathbf{L}_{\mathbf{i}}$. $\mathrm{O}$ mesmo procedimento é usado para avaliar os indicadores de liquidação financeira, substituindo o $\mathbf{F}$, pelo indicador de liquidação financeira.

A utilização dos preços em nível é respaldada em Elam \& Davis (1990) que ressaltam a capacidade desses preços, quando próximos do vencimento, de revelarem o comportamento da base bem como sua utilidade para predizerem o preço alvo resultante de um hedge. Por outro lado, Shafer (1993) sugere que os preços em diferenças são úteis na sinalização do comportamento da base durante o hedge e também permitem predizer o preço alvo esperado como resultado desse.

Uma metodologia alternativa, primeiramente utilizada por Pennings \& Meulenberg (1997), considera explicitamente os riscos de liquidez envolvidos nas negociações futuras. Essa variação está associada à distinção feita pelos autores ao que foi denominado mercados futuros agrícolas estreitos ${ }^{10}$, onde $o$ risco de liquidez terá um impacto sobre a variância dos retornos. Apesar dos

\footnotetext{
${ }^{10}$ mercado com pequeno volume de negociação, onde uma grande posição tomada pode afetar o preço futuro.
} 
mercados futuros (boi gordo e soja) no Brasil se enquadrarem nessa denominação de estreitos, optou-se por não trabalhar com essa metodologia, uma vez que dado o objetivo do trabalho, que é comparar a eficiência de hedging proveniente de formas alternativas de liquidação e metodologias de construção do indicador, essa característica torna-se não relevante.

\subsection{Testando modelos nonnested ${ }^{11}$ das especificações de liquidação}

Uma das principais funções da econometria é testar a validade dos modelos desenvolvidos pela teoria econômica. Contudo, Davidson \& MacKinnon (1981) e Godfrey \& Pesaran (1983) afirmam que muitas técnicas para testar hipóteses, simplesmente permitem testar restrições sobre um modelo mais geral. Uma das exceções a essa generalização é uma técnica sugerida por Pesaran \& Deaton (1978), baseada no trabalho de Cox (1962) e Pesaran (1974). Essa técnica é referenciada como Cox-Pearan-Deaton ou teste CPD, e permite testar a autenticidade de modelos não lineares e de regressões multivariadas, quando existe uma hipótese alternativa nonnested.

A natureza dos processos de liquidação, bem como as determinações de diferenciais e pontos de entrega determinam ao relacionamento de eficiência de hedge diferentes especificações de preço de liquidação. Uma vez que esse relacionamento não pode ser obtido pela imposição de restrições paramétricas, esse representa modelos nonnested. Para avaliar as diferenças

\footnotetext{
11 Dois modelos são ditos nested quando um é caso especial do outro, obtido pelas restrições de parâmetros. Assim, por exemplo, a função de produção de Cobb-Douglas é nested à função de produção de elasticidade de substituição constante (CES). Por outro lado, se um modelo não pode ser expresso como um caso especial do outro, pela restrição de parâmetros, esses são considerados modelos nonnested (Doran, 1993).
} 
estatísticas nas regressões de eficiência de hedging, a abordagem de teste de hipótese é empregada. Essa abordagem confia na predição da performance do modelo baseado no processo de geração de dados (PGD) de preços a vista. A capacidade para predizer a performance do modelo sobre a base do PGD da variável dependente é um conceito chave para testar modelos nonnested e Cox (1962), foi o primeiro autor a usar tal abordagem.

Supondo que a hipótese nula:

$\mathrm{H}_{0}: \mathrm{C}_{\mathrm{i}}=\beta_{0}+\alpha_{0} \mathrm{~F}_{0}+\mu_{0} ; \mu_{0} \sim \mathrm{N}\left(0, \sigma_{0}^{2} \mathrm{I}\right)$

é a verdadeira PGD para $C_{i}$ (preço a vista na localização $L_{i}$ ) onde $F_{0}$ é o vetor preço de liquidação baseado na especificação $S_{0}$. Outra especificação $S_{1}$ com preço de liquidação $F_{1}$ é acreditado para a geração do verdadeiro PGD e é prognosticado na base de $\mathrm{H}_{0}$ :

$\mathrm{H}_{1}: \mathrm{C}_{\mathrm{i}}=\beta_{1}+\alpha_{1} \mathrm{~F}_{1}+\mu_{1} ; \mu_{1} \sim \mathrm{N}\left(0, \sigma_{1}^{2} \mathrm{I}\right)$

Esses dois modelos podem ser combinados dentro de um simples modelo:

$C_{i}=\beta+(1-\delta) \alpha_{0} F_{0}+\delta \alpha_{1} F_{1}+\mu$

Se $\delta=0, H_{0}$ é não rejeitada, enquanto $\delta=1$ implica na não rejeição de $H_{1}$. Dessa forma, $H_{0}$ poderia ser testada, a princípio, testando $\delta=0$. Contudo, desde que os coeficientes de inclinação em $\mathrm{H}_{0}$ e $\mathrm{H}_{1}$ não podem ser estimados 
diretamente de (10), Davidson \& Mackinnon (1981) sugeriram a utilização do valor proposto em $C_{i}$, baseado no modelo dado por $\mathrm{H}_{1}$ em (9), ser usado em (10) e, então, testar se $\delta$ é igual a zero. Quando $\mathrm{H}_{0}$ é verdadeiro, eles mostram que o estimador de $\delta$ dividido pelo erro padrão convencionalmente estimado é assintoticamente distribuído com um padrão normal $\mathrm{N}(0,1)$.

Os passos desses “J-testes” são:

estima-se a regressão: $C_{i}=\alpha_{1} F_{1}+\beta_{1}+\mu_{1}$

tem-se: $\widehat{\mathrm{c}}_{i 1}=\widehat{\alpha}_{1} \mathrm{~F}_{1}+\beta_{1}$

estima-se a regressão: $\mathrm{C}_{i}=(1-\delta) \alpha_{0} F_{0}+\delta \bar{c}_{i 1}+\beta_{1}+\mu$

testa a hipótese: $\delta=0$.

Note que quando $\mathrm{H}_{0}$ está sendo testada, $\mathrm{H}_{1}$ é usada para recusar a adequação de $\mathrm{H}_{0}$. Se acontecer de $\mathrm{H}_{0}$ ser rejeitada, então não será discutido que $\mathrm{H}_{1}$ é o modelo verdadeiro. Para fazer uma declaração sobre a validade de $\mathrm{H}_{1}$, a função tem que ser invertida e o procedimento de teste ser novamente realizado.

\subsection{Métodos e dados}

\subsubsection{0 caso da commodity boi gordo}

Os mercados físicos considerados, no estudo dos contratos futuros de boi gordo, serão Triângulo Mineiro (TM) - MG, Campo Grande (CG) - MS, Paranavaí/Maringá/Londrina (Maringá -NP) - PR, Três Lagoas/Araçatuba 
(Araçatuba - AR) - SP, Presidente Prudente (PP) - SP, Bauru/Marília (Bauru BA) - SP, São José do Rio Preto/Barretos/Votuporanga (São José do Rio Preto SJ) - SP, Goiânia (GO) - GO e Dourados (DO) - MS. Os preços para essas regiões serão obtidos junto ao CEPEA/FEALQ, que é a instituição responsável pela construção do indicador utilizado na liquidação financeira do contrato de boi gordo na BM\&F.

O conjunto formado pelas regiões de Araçatuba (AR), Presidente Prudente (PP), Bauru (BA) e São José do Rio Preto (SJ), será selecionado para compor as regiões participantes da construção do indicador e Triângulo Mineiro (TM), Campo Grande (CG), Maringá (NP), Goiânia (GO) e Dourados (DO) como regiões que não participam do indicador. A escolha dessas regiões é devido à sua importância no cenário nacional, tanto em termos de volume de produção quanto em termos da formação de preços. A não utilização de outras regiões (fora de São Paulo) para comporem o conjunto de localizações formadoras do indicador passa, principalmente, pela diferenciação de tributação entre Estados. Os dados que serão utilizados nesse trabalho, abrangem o período de abril de 1994 a março de 1998 e constituem-se de preços diários.

O ponto de partida da análise será a especificação utilizada nos contratos futuros de boi gordo negociados a partir da implementação da liquidação financeira; no final de 1994. O preço comum de liquidação é uma média ponderada dos preços à vista (seção 4.1), onde os pesos representam probabilidades para uma localização particular tornar-se a opção mais barata. Já o indicador é obtido a partir de uma média das probabilidades calculadas, quando da determinação do preço comum de liquidação, por uma média móvel definida para o período de trinta dias: 
$\mathrm{I}^{\mathrm{APBS}}=\alpha_{\mathrm{AR}} \mathrm{P}_{\mathrm{AR}}+\alpha_{\mathrm{PP}} \mathrm{P}_{\mathrm{PP}}+\alpha_{\mathrm{BA}} \mathrm{P}_{\mathrm{BA}}+\alpha_{\mathrm{SJ}} \mathrm{P}_{\mathrm{SJ}}$

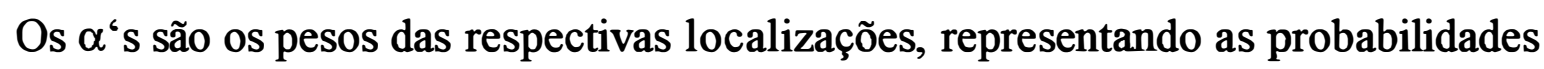
médias de tornar-se a mais barata para entregar, baseado nas especificações mencionadas anteriormente (ver apêndice 4).

Relacionado à questão de prêmios/descontos, definiu-se, arbitrariamente, o horizonte da média móvel como sendo uma semana. Desse modo, busca-se aproximar os preços regionais que compõem o indicador e, posteriormente, executa-se todo o processo já definido para a consecução do preço comum de liquidação e o indicador-EMB (exemplificado no apêndice 5).

\subsubsection{0 caso da commodity soja}

No caso dos mercados futuros de soja, as localizações que comporão a análise são: Ponta Grossa, Norte, Oeste e Sudoeste do Paraná. Nesse trabalho, a região de Ponta Grossa não participará na construção do indicador. Os dados utilizados compreendem o período de 01/09/97 a 15/05/98 e constituem-se de preços diários.

A análise baseia-se na especificação utilizada nos contratos futuros de soja implementados a partir de setembro de 1997. Vale ressaltar que o indicador (PNS) obtido através da Fipe, também será avaliado com relação a sua eficiência e à variância da base. As demais considerações seguem as detalhadas para o boi gordo (4.5.1), alterando apenas as regiões de análise. 


\section{RESULTADOS E DISCUSSÃO}

Esse capítulo apresenta e analisa a performance das especificações de criação dos indicadores. Os quatro métodos de construção de indicadores analisados foram: (a) baseado em um único ponto; (b) esquema de ponderação pela probabilidade de entrega mais barata para múltiplas localizações com e sem diferencial de preço; e, (c) indicadores utilizados atualmente pelos contratos negociados. Cada tipo de especificação é avaliado separadamente com respeito a sua eficiência na liquidação e então comparações são feitas entre elas. Finalmente, os resultados da avaliação dos testes de hipóteses são apresentados.

5.1 Análise dos resultados obtidos para os contratos de boi gordo

5.1.1 Eficiência de hedging medida entre os preços físicos de cada região e as formas de liquidação dos contratos

Como especificação de um indicador, baseado no preço de um único local, tomou-se o preço da região de Araçatuba. O preço comum para a liquidação dos contratos com múltiplas localizações (PCL) e o indicador (IEMB), considera os preços de quatro regiões do Estado de São Paulo: 
Araçatuba, Presidente Prudente, Bauru e São José do Rio Preto, sendo que no caso do preço comum de liquidação e do indicador que utilizam prêmios/descontos (PCLPD e IEMBPD, respectivamente), a região tomada como base foi a de Araçatuba.

Pela Tabela 3 pode-se observar os níveis de eficiência de hedging individuais para as localizações que participam ou não da construção do indicador. Os resultados evidenciam que os tipos de especificações analisadas produzem aproximadamente o mesmo grau de eficiência para todas as regiões. Relacionado às eficiências obtidas entre as especificações e o preço futuro (PF), as únicas diferenciações ficaram por conta do preço comum de liquidação (PCL) e o indicador-EMB (IEMB) que foram superiores às demais, em torno de 1 a $2 \%$.

Os resultados apresentados na Tabela 3 podem ser interpretados, por exemplo, como a variação no preço da região de Campo Grande (CG) sendo explicado, em $94,71 \%$ dos casos, pela variação do indicador boi gordo (IBG). A região que não participa do indicador que é melhor explicada pelas especificações de liquidação é a do Triângulo Mineiro (TM) e a que apresentou o pior coeficiente de determinação $\left(\mathrm{R}^{2}\right)$ foi a região de Dourados $(\mathrm{DO})$.

A eficiência de hedging para $o$ boi gordo medida entre as localizações individuais e o preço futuro (PF), na Tabela 3, foram relativamente pequenas quando comparadas às da soja (Tabela 6). A razão, possivelmente, esta relacionada ao fato do boi gordo ser uma commodity não-estocável. Tal consideração baseia-se na sugestão teórica de Leuthold et al. (1989) de que para commodities não-estocáveis, a decisão de variar a produção é a principal influência na relação de preços para esses produtos. Uma vez que essas mercadorias não se baseiam em proporções fixas de estoques, como no caso dos 
grãos, os mercados futuros constituem-se principalmente uma antecipação dos preços. A base para animais vivos (boi gordo) é conduzida, portanto, pela oferta e demanda e pela expectativa por parte dos traders de que essas funções variem ao longo do tempo. Desse modo, o conjunto de preços a vista e a futuro não é formalmente relacionado para o período que precede o vencimento do contrato, além da não existência de um limite teórico máximo ou mínimo para o tamanho da base.

Tabela 3 - Eficiência de hedging sobre especificações alternativas de liquidação semana de vencimento

\begin{tabular}{lllllll|c}
\hline & AR & IBG & PCL & IEMB & PCLPD & IEMBPD & PF \\
\hline AR & 1,00 & 0,99 & 0,99 & 0,99 & 0,99 & 0,99 & 0,55 \\
PP & 0,99 & 0,99 & 0,99 & 0,99 & 0,99 & 0,99 & 0,57 \\
BA & 0,99 & 0,99 & 0,99 & 0,99 & 0,99 & 0,99 & 0,56 \\
SJ & 0,97 & 0,97 & 0,97 & 0,97 & 0,96 & 0,96 & 0,51 \\
\hline CG & 0,94 & 0,94 & 0,94 & 0,94 & 0,94 & 0,94 & 0,51 \\
GO & 0,95 & 0,96 & 0,96 & 0,96 & 0,95 & 0,95 & 0,52 \\
TM & 0,96 & 0,97 & 0,97 & 0,96 & 0,96 & 0,96 & 0,58 \\
NP & 0,94 & 0,95 & 0,95 & 0,95 & 0,94 & 0,94 & 0,63 \\
DO & 0,92 & 0,93 & 0,92 & 0,92 & 0,92 & 0,92 & 0,59 \\
\hline PF & 0,55 & 0,54 & 0,56 & 0,56 & 0,55 & 0,55 & - \\
\hline
\end{tabular}

Fonte: dados da pesquisa.

$\mathrm{AR}, \mathrm{PP}, \mathrm{BA}, \mathrm{SJ}, \mathrm{CG}, \mathrm{GO}$, TM, NP e DO, correspondem respectivamente aos preços físicos nas regiões de Araçatuba, Presidente Prudente, Bauru, São José do Rio Preto, Campo Grande, Goiânia, Triângulo Mineiro, Norte do Paraná e Dourados. IBG, PCL, IEMB, PCLPD, IEMBPD e PF são siglas que referem-se a: indicador do boi gordo, preço comum de liquidação, indicador ponderado pela entrega mais barata, preço comum de liquidação com prêmio/desconto e indicador ponderado pela entrega mais barata com prêmio/desconto e preço futuro, respectivamente.

Os resultados obtidos para a eficiência de hedging para a semana de vencimento sugerem que os preços físicos das localizações, que participam ou 
não da construção do indicador, são altamente explicados por qualquer especificação (AR, IBG, PCL, IEMB, PCLPD e IEMBPD) de liquidação. Essa constatação pode estar relacionada às evidências obtidas por De Zen (1997), de que existe uma alta integração de preços entre as regiões analisadas, onde cada localização apresenta respostas rápidas a alterações em outras, além da não existência de lideres no mercado. Esse autor infere também, que alterações de preços podem ser causadas por fatores próprios de cada região e transmitidas às outras. Devido à elevada capacidade de auto-previsão e de prever os preços de outras regiões, além de figurar regiões importantes no tocante a produção e processamento, essas especificações, como sugerido por Barros et al. (1997), podem ser creditadas como possuindo um alto potencial de credibilidade e visibilidade.

5.1.2 Variância da base entre os preços físicos de cada região e as especificações alternativas de liquidação

Procedendo-se a uma análise da Tabela 4, pode-se inferir que as variâncias das diferenças entre os preços das localizações e as especificações de liquidação apresentaram valores relativamente baixos. Contudo, algumas observações devem ser destacadas no sentido de diferenciações relacionadas a aumentos ou diminuições na variância quando se compara as demais especificações com a que rege, atualmente, os contratos de boi gordo comercializados na $\mathrm{BM} \& \mathrm{~F}$, o indicador do boi gordo (IBG).

As especificações que obtiveram melhores desempenhos quando comparadas ao IBG foram: PCL e IEMB para a região de Araçatuba (AR), onde identifica-se reduções na base em torno de 45\%; na região de Presidente Prudente 
(PP) observa-se reduções significativas quando se utiliza as especificações $A R$ (28,73\%), PCL (70,72\%) e IEMB (70,17\%); e, na região de Bauru (BA) onde as reduções ficaram ao redor de $33 \%$ para as especificações AR, PCLPD e IEMBPD, e 67\% para PCL e IEMB. Por outro lado, os piores desempenhos comparativos ficaram por conta do PCLPD e IEMBPD para as regiões de Araçatuba (AR) e São José do Rio Preto (SJ), onde observa-se reduções, ao se substituir essas especificações em favor do IBG, de 46,90\% e 31,64\%, respectivamente. Para as demais localizações, as alterações da variância da base quando avaliadas entre o IBG e as outras especificações não foram significativas. A análise da variância da base relacionada com as demais especificações de liquidação e o preço futuro (PF) apresentou uma redução quando comparada com a utilizada atualmente (IBG), que variou de $0,50 \%$ para a especificação AR até $2,69 \%$ para a PCL.

Tabela 4 - Variância da base entre o preço físico das regiões de estudo e as especificações de liquidação (AR, PCL, IEMB, IBG, PCLPD e IEMBPD) - semana do vencimento

\begin{tabular}{lccccccccc|c}
\hline & AR & PP & BA & SJ & CG & GO & TM & NP & DO & PF \\
\hline AR & 0,000 & 0,0129 & 0,0251 & 0,1941 & 0,5465 & 0,3805 & 0,2590 & 0,4641 & 0,3312 & 6,6298 \\
PCL & 0,0042 & 0,0053 & 0,0125 & 0,2055 & 0,5252 & 0,3685 & 0,2382 & 0,4254 & 0,3165 & 6,4841 \\
IEMB & 0,0041 & 0,0054 & 0,0124 & 0,2055 & 0,5245 & 0,3683 & 0,2385 & 0,4254 & 0,3165 & 6,4867 \\
IBG & 0,0077 & 0,0181 & 0,0382 & 0,2031 & 0,5410 & 0,3464 & 0,2334 & 0,4395 & 0,3084 & 6,6634 \\
PCLPD & 0,0145 & 0,0186 & 0,0257 & 0,2971 & 0.5473 & 0,3929 & 0,2586 & 0,4513 & 0,3484 & 6,5735 \\
EMBPD & 0,0145 & 0,0186 & 0,0257 & 0,2971 & 0,5476 & 0,3929 & 0,2586 & 0,4514 & 0,3485 & 6,5738 \\
\hline
\end{tabular}

Fonte: dados da pesquisa

Os resultados obtidos sugerem uma preocupação no sentido de se buscar a redução na variância da base entre as localizações analisadas e a especificação de liquidação corrente (IBG), e consequentemente, melhorias na sua visibilidade e na sua representatividade. Essa preocupação relaciona-se à 
questão levantada por Barros et al. (1997) que ressaltam a boa visibilidade e a representatividade do indicador como condições básicas na sua aceitação por parte do mercado, para fins de liquidação dos contratos futuros.

A análise considerando-se, paralelamente, as especificações IBG e Ar, indica que apesar da eficiência de ambas serem praticamente iguais, o desempenho com relação à variância da base quando se utiliza o IBG é superior, apresentando uma menor variância e, portanto, sendo reputado com uma melhor visibilidade e representatividade. Ao se comparar as especificações PCL e IEMB com o IBG pode-se constatar que a eficiência de hedging apresentou valores praticamente iguais. Contudo, referente à variância da base, a especificação PCL e IEMB obtiveram melhores resultados, evidenciando, portanto, que as especificações baseadas na probabilidade de entrega mais barata proporcionariam uma melhor visibilidade e representatividade frente ao mercado. Desse modo, torna-se evidente uma reavaliação no esquema de ponderação utilizado pelo IBG, uma vez que apesar de ambos terem sido altamente eficientes, a variância da base entre os preços físicos locais e o IBG foi em sua maioria superior a alcançada pelo PCL e pelo IEMB. A utilização das especificações PCL e IEMB reorganizadas através da definição de prêmios e descontos (PCLPD e IEMBPD) apresentou desempenho inferior às originais e ao IBG com relação à variância da base. Esse resultado não necessariamente descarta a sua possível utilização para fins de liquidação de contratos, sendo mister, contudo, o estudo de formas alternativas de prêmios e descontos que conduzam a uma melhor visibilidade e representatividade. 


\subsubsection{Resultados dos testes de hipóteses com J-Testes}

Os resultados dos testes non-nested, que identifica quais especificações de construção do indicador são menos rejeitadas em favor das demais, são apresentados na Tabela 5. Por exemplo, na linha dois e coluna três é mostrado que a especificação de indicador ponderado pela probabilidade de localização mais barata (IEMB) não é rejeitada em favor da especificação corrente (IBG) em dois dos oito mercados testados. Isto não significa, contudo, que nos seis mercados remanescentes, a especificação corrente é preferida à IEMB. Similarmente, quando se inverte essa tabela o resultado obtido corresponde ao número de mercados em que o IBG não é rejeitado em favor do IEMB. Uma análise geral da Tabela 5 identifica a especificação IEMB com uma ligeira vantagem sobre as demais, uma vez que essa obtém nove não rejeições em um total de 24 possíveis (oito localizações vezes três especificações), enquanto as especificações IBG, AR e IEMBPD não são rejeitadas em sete, oito e sete mercados, respectivamente.

Tabela 5 - Resultados dos testes de hipóteses para a commodity boi gordo - o número máximo de mercados onde pode-se não rejeitar a hipótese nula é oito

\begin{tabular}{lcccc}
\hline & EEMB & IBG & AR & IEMBPD \\
\hline IEMB & - & 2 & 4 & 3 \\
IBG & 2 & - & 2 & 3 \\
AR & 3 & 2 & - & 3 \\
IEMBPD & 1 & 3 & 3 & - \\
\hline
\end{tabular}

Fonte: dados da pesquisa 
As especificações PCL e PCLPB foram omitidas da análise de testes por não apresentarem diferenciações perceptíveis em relação às IEMB e IEMBPD, desse modo, o que vale para essas, pode ser estendido àquelas.

\subsection{Análise dos resultados obtidos para os contratos de soja cambial}

\subsubsection{Eficiência de hedging medida entre os preços físicos de cada região e as formas de liquidação dos contratos}

Relacionado à análise de eficiência da commodity soja cambial, utilizou-se a região Norte do Paraná para compor o indicador baseado em uma única localização. A essa região foi acrescentado as regiões Sudoeste e Oeste para formarem o conjunto de localizações que determinam o preço comum de liquidação dos contratos. No caso das especificações determinadas a partir dos prêmios/descontos, tomou-se a região Norte do Paraná como referencial.

Os níveis de eficiência obtidos a partir das regressões entre os

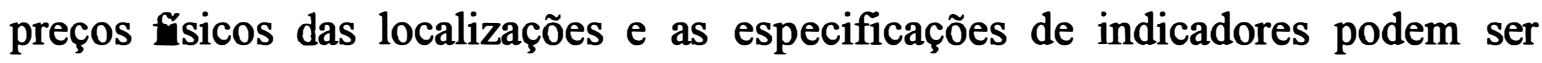
visualizados na Tabela 6. Observa-se que as eficiências entre as localizações avaliadas e as especificações (IPS e as ponderadas pela probabilidade da localizações mais baratas) foram altamente significativas (entre 97 e 99\%), ficando a exceção por conta da especificação PNS que apresentou resultados variando de 75 a $94 \%$. Isto permite sugerir que os indicadores analisados podem ser respaldados como representativos e com potencial de credibilidade, sendo que tal inferência pode ser creditada à existência de uma integração de preços entre as localizações que compõem esses indicadores, apesar do desconhecimento de 
trabalhos que a comprovem. A menor eficiência apresentada pelo PNS, quando comparada às demais, em relação às regiões analisadas, pode estar relacionada ao maior número de localizações que essa representa, e também, à questão de considerar vários Estados na sua composição. Tal resultado reforça o obtido em Barros et al. (1997) que ressalta, adicionalmente, que o PNS é calculado mediante ponderação com base na produção, possuindo fortes evidências de apresentar piores resultados quando comparados às ponderações pautadas no volume ou capacidade de processamento de cada praça.

Tabela 6 - Eficiência de hedging sobre especificações alternativas de liquidação semana de vencimento

\begin{tabular}{lccccccc|c}
\hline & NP & PCL & IEMB & PNS & IPS & PCLPD & IEMBPD & PF \\
\hline NP & 1,00 & 0,99 & 0,99 & 0,90 & 0,99 & 0,99 & 0,99 & 0,97 \\
SO & 0,99 & 0,99 & 0,99 & 0,94 & 0,99 & 0,99 & 0,99 & 0,97 \\
OE & 0,99 & 0,99 & 0,99 & 0,91 & 0,99 & 0,99 & 0,99 & 0,96 \\
PG & 0,97 & 0,99 & 0,99 & 0,75 & 0,98 & 0,99 & 0,99 & 0,91 \\
\hline PF & 0,97 & 0,97 & 0,97 & 0,87 & 0,96 & 0,97 & 0,97 & \\
\hline
\end{tabular}

Fonte: dados da pesquisa.

$\mathrm{NP}, \mathrm{SO}, \mathrm{OE}, \mathrm{PG}$ correspondem às regiões Norte, Sudoeste, Oeste e Ponta Grossa do Estado do Paraná. PCL, IEMB, PNS, IPS, PCLPD, IEMBPD e PF são siglas que referem-se a: preço comum de liquidação, indicador ponderado pela entrega mais barata, preço nacional da soja, indicador do preço da soja, preço comum de liquidação com prêmio/desconto, indicador ponderado pela entrega mais barata com prêmio/desconto e preço futuro, respectivamente.

Os resultados das eficiência entre as localizações e os preços futuros (PF), apresentaram valores bem superiores aos encontrados no caso da commodity boi gordo, esse fato, como mencionado anteriormente, pode ser creditado à questão de uma commodity ser estocável e a outra não. 


\subsubsection{Variância da base entre os preços físicos de cada região e as especificações alternativas de liquidação}

A partir das variâncias da base entre o preço físico das localizações individuais e as especificações analisadas, apresentadas na Tabela 7, pode-se observar que os resultados alcançados através da especificação PNS foram os que obtiveram as maiores variâncias quando comparados às demais, sendo, portanto, considerado $\mathrm{o}$ indicador com pior visibilidade e credibilidade entre todos os analisados. Deve-se ressaltar, contudo, o fato de que o indicador PNS, como dito anteriormente, considera um maior número de regiões e em mais de um Estado, e as análises procedidas para a soja considera apenas as localizações do Estado do Paraná que compõem o indicador utilizado atualmente. A determinação das variâncias entre as especificações e os preços futuros (PF), também identificou o indicador PNS como sendo o portador do pior desempenho, ou seja, na data de liquidação dos contratos, o preço futuro é forçado a convergir para o indicador, contudo, uma vez que esse é formado no mercado físico enquanto aquele é determinado no mercado futuro, geralmente existirá uma diferença entre eles, que é definida como base, assim, quanto maior for a variância dessa base, maior é a arbitrariedade imposta e, consequentemente, mais difícil será a aceitação dessa especificação por parte dos integrantes do mercado.

As especificações que consideram a probabilidade da localização mais barata apresentaram resultados inferiores ao indicador IPS para a região de Ponta Grossa (PG) e, também, com relação ao preço futuro (PF). Essa situação pode estar associada às deficiências inerentes às séries de preços das regiões de Ponta Grossa e do Porto de Paranaguá que, impossibilitaram as suas inclusões na composição dos indicadores alternativos. 
Tabela 7 - Variância da base entre o preço físico das regiões de estudo e os indicadores (NO, PCL, IEMB, PNS, IPS, PCLPD e IEMBPD) semana do vencimento

\begin{tabular}{lcccc|c}
\hline & NO & SO & OE & PG & PF \\
\hline NO & 0,0000 & 0,1490 & 0,1877 & 0,3066 & 0,4732 \\
PCL & 0,1821 & 0,0937 & 0,0001 & 0,5470 & 1,1447 \\
IEMB & 0,1811 & 0,0934 & 0,0001 & 0,5474 & 1,1446 \\
PNS & 4,7564 & 5,9034 & 6,5969 & 1,9826 & 2,7183 \\
IPS & 0,0349 & 0,1649 & 0,2160 & 0,1213 & 0,5177 \\
PCLPD & 0,1805 & 0,0949 & 0,0001 & 0,5468 & 1,1419 \\
IEMBPD & 0,1804 & 0,0946 & 0,0001 & 0,5471 & 1,1418 \\
\hline
\end{tabular}

Fonte: dados da pesquisa

$\mathrm{O}$ indicador baseado nos preços de uma única localização (NO) apresentou variâncias menores do que a especificação atual (IPS) em todos os mercados, incluindo o preço futuro (PF), ficando a única exceção por conta da região de Ponta Grossa (PG). Nesse caso, a utilização de preços de várias localizações para compor o indicador, visto que a razão de sua utilização é a redução da variância da base entre ele e os preços físicos locais, não se faz necessário. Contudo, a questão que pode ser levantada está relacionada à maior facilidade de manipulação do mercado, quando se constrói um indicador que considera apenas uma localização como fonte de dados.

\subsubsection{Resultados dos testes de hipóteses com J-Testes}

Os resultados dos testes non-nested para a commodity soja identificando as especificações de indicador menos rejeitada em favor das demais, são mostradas na Tabela 8. Na avaliação desses testes foram considerados três 
mercados (Norte, Oeste e Sudeste do Paraná), assim, as especificações evidenciadas podem apresentar doze não rejeições no cômputo geral (três localizações vezes quatro especificações), sendo a análise realizada similarmente àquela feita no caso da commodity boi gordo.

Apesar da especificação ponderada pela probabilidade da localização mais barata apresentar uma não rejeição em favor do indicador atual (IPS) e o contrário não ocorrer, não existe uma vantagem definida entre elas, uma vez que o número de não rejeições, de ambas as especificações, é igual a cinco na soma total. $\mathrm{O}$ indicador baseado em localizações de vários Estados (PNS) foi 0 que obteve o pior desempenho nos testes, onde foi não rejeitado em apenas um mercado quando comparado à especificação NO, sendo, também, o indicador onde as outras especificações obtiveram o maior número de não rejeições.

Tabela 8 - Resultados dos testes de hipóteses para a commodity soja - o número máximo de mercados onde pode-se não rejeitar a hipótese nula é três

\begin{tabular}{lccccc}
\hline & IEMB & IPS & NO & PNS & IEMBPD \\
\hline IEMB & - & 1 & 1 & 3 & 0 \\
IPS & 0 & - & 2 & 3 & 0 \\
NO & 0 & 1 & - & 2 & 0 \\
PNS & 0 & 0 & 1 & - & 0 \\
IEMBPD & 0 & 1 & 1 & 3 & - \\
\hline
\end{tabular}

Fonte: dados da pesquisa

Como ocorreu no caso da commodity boi gordo, as especificações PCL e PCLPB, também, foram omitidas da análise de testes por não apresentarem diferenciações perceptíveis em relação às IEMB e IEMBPD, respectivamente. 


\section{CONCLUSÕES}

Os resultados obtidos identificaram que todas as especificações de construção dos indicadores analisados, tanto para a commodity boi quanto para a soja, produzem um alto grau de eficiência quando comparadas às regiões participantes ou não do indicador. Essa performance justifica a inclusão de tais indicadores como detentores de um alto potencial de credibilidade e visibilidade. Os resultados sugerem, também, que a especificação utilizada atualmente na liquidação dos contratos da soja cambial (IPS) apresenta uma melhor eficiência do que sua antecessora (PNS).

$\mathrm{Na}$ análise da variância da base entre os preços físicos de cada região e as especificações de liquidação, relacionada à commodity boi gordo, constata-se que as especificações ponderadas pela probabilidade da localização mais barata apresentaram uma ligeira vantagem sobre as demais, incluindo-se o indicador atual (IBG). Para o caso da soja, a especificação que apresentou menor variância foi a construída a partir de uma única localização (NO), seguida pela atual (IPS), podendo ser creditadas como apresentando uma maior visibilidade e representatividade do mercado perante as demais.

Os testes realizados, com $\mathrm{o}$ intuito de identificação das especificações menos rejeitadas em favor das demais, apresentaram ligeira 
vantagem ao indicador ponderado pela probabilidade da localização mais barata (IEMB) no caso da commodity boi gordo. Relacionado à soja as especificações IEMB e IPS obtiveram resultados iguais no cômputo geral.

Vale a pena levantar alguns problemas enfrentados no desenvolvimento desse trabalho. $O$ primeiro refere-se à pequena amostra de preços regionais da soja para os contratos que utilizam o IPS como instrumento de liquidação dos contratos. O segundo relaciona-se à quebra da seqüência dos preços da soja para algumas regiões, impossibilitando a sua utilização na análise. Contudo, deve-se ressaltar que esses problemas estão associados diretamente à realização desse estudo, sendo porém contornado com o passar do tempo, onde novos dados serão incorporados à série existente.

Quando se analisa a eficiência de hedging, a teoria, geralmente, remete a uma analogia entre os preços físicos e futuros, contudo, esse trabalho evidencia funções alternativas para medir a eficiência para contratos liquidados financeiramente, fazendo uma comparação entre os preços físicos locais e os indicadores. Essa metodologia vem de encontro à proposta de que existe uma convergência entre os preços físicos e futuros na data de liquidação dos contratos. Desse modo, esse estudo avaliou o grau de precisão relativo a cada especificação de liquidação que pode ser utilizada para liquidar os contratos futuros das commodities boi gordo e soja comercializados na BM\&F.

A especificação baseada nos diferenciais de preços (prêmios/descontos), apesar de não apresentar resultados surpreendentes, tanto para boi gordo como para soja, deve ser ressaltada. O comentário que se faz refere-se a um aprofundamento na discussão que conduza a prêmios/descontos 
que possibilitem uma maior visibilidade e previsibilidade do indicador, possibilitando, assim, sua incorporação no mecanismo de liquidação.

A partir das evidências obtidas através desse trabalho, deve-se ressaltar a necessidade de um maior número de estudos, por parte das instituições de pesquisa, relacionados ao desenvolvimento dos indicadores utilizados na liquidação dos contratos futuros. Vale salientar, também, que essa preocupação já pode ser sentida no CEPEA/FEALQ, com relação aos indicadores que desenvolve. 


\section{REFERÊNCIAS BIBLIOGRÁFICAS}

BARROS, G.S de C.; FERREIRA FILHO, J.B. de S.; ZEN, S. de; COUTO, M.T.

Relatório de pesquisa: metodologia, implantação e primeiros resultados. Piracicaba: FEALQ, 1994.

BARROS, G.S de C.; MARQUES, P.V.; BACCHI, M.R.P.; CAFFAGNI, L.C. Elaboração de indicadores de preços de soja: um estudo preliminar. Piracicaba: FEALQ/ESALQ, 1997.

BESSADA, O. O mercado futuro e de opç̃es. 3 ed. Rio de Janeiro: Record, 1995. 297p.

BOLSA DE MERCADORIAS \& FUTUROS. Síntese de dados. 1997. http://www.bmf.com.br.

BOYLE, P. The quality option and timing in futures contracts. Journal of Finance, v.44, n.1, Mar. 1989.

BUENO, A.J.T. O preço nacional da soja - metodologia e algumas conclusões resultantes de seu acompanhamento diário. Resenha BM\&F, n.106, ago./out. 1995. 
CHAHERLI, N.M.; HAUSER, R.J. Delivery systems versus cash settlement in corn and soybean futures contracts. OFOR paper number 95-02, Feb. 1995.

COHEN, L.; GORHAM, M. The projected impact of cash-settled commodity contracts on cash/futures price relationships. In: NCR-134 CONFERENCE ON APPLIED COMMODITY PRICE ANALYSIS, FORECASTING, AND MARKET RISK MANAGEMENT. Chicago, p.313-335, May 1985.

COX, D.R. Further results on tests of separate families of hypotheses. Journal of the Royal Statistical Society. Séries B, v.24, n.2, p.406-424, Jan./Febr. 1962.

DAVIDSON, R.; MACKINNON, J.G. Several tests for model selection in the presence of alternative hypoteses. Econometrica, v.49, n.3, p.781-793, May 1981.

DE ZEN, S. de. Integração entre os mercados de boi gordo e de carne bovina no centro-sul do Brasil. Piracicaba, 1997. 81p. Dissertação (Mestrado) Escola Superior de Agricultura "Luiz de Queiroz", Universidade de São Paulo.

DITSCH, M.W.; LEUTHOLD, R.M. Evaluation the potential of the lean hog futures contract. OFOR paper number 96-03, Aug. 1996.

DORAN, H. Testing nonnested models. American Journal of Agricultural Economics, v.75, n.1, p.95-103, Febr. 1993. 
DOWNES, J.; GOODMAN, J.E. Dicionário de termos financeiros e de investimento. São Paulo: Nobel, 1993. 650p.

EDERINGTON, L. The hedging performance of a new contract. Journal of Finance, v.34, n.1, p.157-170, Febr. 1979.

ELAM, E. Estimated hedging risk with cash settlement feeder cattle futures. Western Journal of Agricultural Economics, v.13, n. 1, p.45-52, Jul. 1988

ELAM, E.; DAVIS, J. Hedging risk for feeder cattle with a traditional hedge compared to a ratio hedge. Southern Journal of Agricultural Economics, n.22, p.209-216, 1990.

FRICK, O.O. Os indicadores de preço nos mercados futuros. Resenha BM\&F, n.111, p.34-40, jul. 1996.

GARBADE, K.D.; SILBER, W.L. Cash settlement of futures contracts: an economic analysis. The Journal of Futures Markets, v.3, n.4, p.451-472, June 1983a.

GARBADE, K.D.; SILBER, W.L. Futures contracts on commodities with multiple varieties: an analysis of premiums and discounts. Journal of Business, v.56, n.3, p.249-272, Jul. 1983b.

GARBADE, K.D.; SILBER, W.L. Structural organization of secondary markets: clearing frequency, dealer activity and liquidity risk. Journal of Finance, v.34, Jun. 1979. 
GODFREY, L.G.; PESARAN, M.H. Tests of non-nested regression models: small sample adjustments and Monte Carlo evidence. Journal of Econometrics, v.21, n.1, p.133-154, Jan. 1983.

HAUSER, R.J.; CHAHERLI, N.M.; THOMPSON, S.R. Cash settlement for corn and soybeans: a preliminary analysis. In: NCR-134 CONFERENCE ON APPLIED COMMODITY PRICE ANALYSIS, FORECASTING AND MARKET RISK MANAGEMENT. 1992.

HULL, J. Introdução aos mercados futuros e de opções. São Paulo: Cultura, 1991. 410p.

JOHNSON, H. Options on the maximum or the minimum of several assets. Journal of Financial Quantitative Analysis, v.22, n.3, p.227-283, Sep. 1987.

JONES, F.J. The economics of futures and options contracts based on cash settlement. The Journal of Futures Markets, v.2, n.1, p.63-82, Febr. 1982.

KAHL, K.H.; HUDSON, M.A.; WARD, C.E. Cash settlement issues for live cattle futures contracts. The Journal of Futures Markets, v.9, n.3, p.237248, May 1989.

KENYON, D. Impact of cash settlement on Virginia fall feeder cattle basis. Paper presented at the American Agricultural Economics Association Meeting, Knoxville, TN, 1988. 
KENYON, D.; BAINBRIDGE, B.; ERNST, R. Impact of cash settlement on feeder cattle basis. Western Journal of Agricultural Economics, v. 16, n.1, p.93-105, 1991.

KIMLE, K.; HAYENGA, M.L. Cash settlement as an alternative settlement mechanism for the live hog futures contract. The Journal of Futures Markets, v.14, n.3, p.347-361, May 1994.

LAZZARINI, S.G. Inovação e organização de bolsas de futuros: teoria e evidências no agribusiness brasileiro. São Paulo, 1997. 216p. Dissertação (Mestrado) - Faculdade de Economia, Administração e Contabilidade, Univerdade de São Paulo.

LEUTHOLD, R.M. Cash settlement versus physical delivery: the case of livestock. The Review of Futures Markets, v.11, n.2, 1992.

LEUTHOLD, R.M.; JUNKUS, J.C.; CORDIER, J.E. The theory and practice of futures markets. Lexington: Lexington books, 1989. 410p.

LIEN, D.D. Cash settlement provisions on futures contracts. The Journal of Futures Markets, v.9, n.3, p.263-270, May 1989.

MARGRABE, W. The value of an option to exchange one asset for another. Journal of Financial, v.33, n.1, p.177-186, Mar. 1978.

MYERS, R.J.; THOMPSON, S.R. Generalized optimal hedge ratio estimation. American Journal of Agricultural Economics, v.71, n.4, p.858-867, Nov. 1989. 
PAUL, A.B. Pricing implications of alternative delivery mechanisms for futures contracts. In: PURCELL, W.D.; ROWSELL, J.B. Key issues in livestock pricing: a perspective for the 1990s. Blacksburg: Research Institute on Livestock Pricing, 1987, p.55-94.

PAUL, A.B. The role of cash settlement in futures contracts specification. In: PECK, A.E., (Ed.). Futures markets: regulatory issues. Washington: American Enterprise Institute for Public Policy Research, 1985. p.271-328.

PENNINGS, J.M.E.; MEULENBERG, M.T.G. The hedging performance in new agricultural futures markets: a note. Agribusiness, v.13, n.3, p.295-300, May 1997.

PESARAN, M.H. On the general problem of model selection. Review of Economic Studies, v.41, n.2, p.153-171, April 1974.

PESARAN, M.H.; DEATON, A.S. Testing non-nested nonlinear regression models. Econometrica, v.46, n.3, p.677-694, May 1978.

PURCELL, W.D. Agricultural futures and options: principles and strategies. New York: Macmillian, 1991. 363p.

PURCELL, W.D.; HUDSON, M.A. The certificate system for delivery in live cattle: conceptual issues and measures of performance. The Journal of Futures Markets, v.6, n.3, p.461-475, May 1986. 
RENCHER, A.C. Methods of multivariate analysis. New York: John Wiley \& Sons, 1995. 627p.

RICH, D.R.; LEUTHOLD, R.M. Feeder cattle cash settlement: hedging risk reduction or illusion?. The Journal of Futures Markets, v.13, n.5, p.497514, Aug. 1993.

RICH, D.R.; LEUTHOLD, R.M.; HUDSON, M.A. Feeder cattle cash settlement: impacts on basis variability in selected U.S. markets. NCR-134 CONFERENCE ON APPLIED COMMODITY PRICE ANALYSIS, FORECASTING, AND MARKET RISK MANAGEMENT, 1990, p.80-94.

ROCHELLE, T.C.P. O contrato futuro de boi gordo: uma análise do impacto da introdução de liquidação financeira sobre o risco da base. Piracicaba, 1997. 140p. Dissertação (Mestrado) - Escola Superior de Agricultura "Luiz de Queiroz", Universidade de São Paulo.

ROWSELL, J.B.; PURCELL, W.D. Impact of cash settlement on the effectiveness of price discovery processes in feeder cattle. In: NCR-134 CONFERENCE ON APPLIED COMMODITY PRICE ANALYSIS, FORECASTING, AND MARKET RISK MANAGEMENT. 1990. p.37-50.

SCHROEDER, T.C.; MINTERT, J. Hedging feeder steers and heifers in the cash-settled feeder cattle futures markets. Western Journal of Agricultural Economics, v.13, n.2, p.316-326, 1988.

SHAFER, C.E. Hedge ratios and basis behavior: an intuitive insight. Journal of Futures Markets, v.13, n.8, p.837-847, Dec. 1993. 
STULZ, R.M. Options on the minimum or the maximum of two risky assets. Journal of Financial Economics, v.10, n.1, p.161-185, March 1982. 


\section{APÊNDICES}




\section{APÊNDICE 1}

Contrato futuro cambial de boi gordo 


\section{Especificações do Contrato Futuro Cambial de Boi Gordo}

\section{Objeto de negociação}

Boi gordo acabado para abate.

Tipo: bovinos machos, castrados, bem acabados (carcaça convexa), em pasto ou confinamento.

Peso: vivo individual entre o mínimo de $\mathbf{4 5 0}$ quilos e máximo de $\mathbf{5 5 0}$ quilos, verificado na balança do local de entrega.

Idade máxima: 60 meses.

2. Cotação

Pontos por arroba líquida, com duas casas decimais, sendo cada ponto equivalente à taxa de câmbio média entre as operações de venda de dólar dos Estados Unidos, para entrega pronta, contratada nos termos da Resolução 1690/90, do Conselho Monetário Nacional-CMN, e divulgada pelo Banco Central do Brasil-Bacen.

3. Variação mínima de apregoação

0,01 ponto (equivalente a US\$0,01) por arroba líquida.

4. Oscilação máxima diária O limite de oscilação será fixado pela BM\&F.

A BM\&F poderá, a qualquer momento, alterar os limites de oscilação, bem como sua aplicação aos diversos vencimentos.

5. Unidade de negociação

330 arrobas líquidas.

6. Meses de vencimento

Todos os meses.

7. Número de vencimentos em aberto

No máximo quinze.

8. Data de vencimento e último dia de negociação

Último dia útil do mês de vencimento.

9. Day trade

São admitidas operações de compra e venda para liquidação diária (day trade), desde que realizadas no mesmo pregão, pelo mesmo cliente (ou operador especial), intermediadas pela mesma corretora de mercadorias e registradas pelo mesmo membro de compensação. Os resultados auferidos nessas operações são movimentados financeiramente no dia útil seguinte ao de sua realização. $O$ valor em dólares será convertido em reais pela taxa de câmbio (TC) definida no item 10 .

10. Ajuste diário

As posições em aberto ao final de cada pregão serão ajustadas com base no preço de ajuste do dia, estabelecido no call de fechamento, conforme regras da Bolsa, com movimentação financeira no dia útil subseqüente.

O ajuste diário será calculado de acordo com as seguintes fómulas:

a) ajuste das operações realizadas no dia $A D=\left(P A^{t}-P O\right) \times T C \times 330 \times n$

b) ajuste das posič̃es em aberto no dia anterior

$A D=\left(P A^{t}-P A^{t-1}\right) \times T C \times 330 \times n$ onde:

$A D=$ valor do ajuste diário;

$\mathrm{PA}^{\mathrm{t}}=$ preço de ajuste do dia;

$\mathrm{PO}=$ preço da operação;

TC = taxa de câmbio de reais por dólar dos Estados Unidos, para entrega pronta, verificada no dia, contratada nos termos da Resolução 1690/90, do CMN, definida como a taxa média de venda apurada pelo Bacen, segundo critérios por ele definidos, e divulgada através do Sisbacen, transação PTAX800, opção "5-L" (cotação de fechamento), e que será utilizada com até quatro casas decimais; 
$\mathrm{n}=$ número de contratos;

$\mathrm{PA}^{\mathrm{t}-1}=$ preço de ajuste do dia anterior.

O valor do ajuste diário, se positivo, será creditado ao comprador e debitado ao vendedor. Se o valor for negativo, será debitado ao comprador e creditado ao vendedor.

- Condições especiais

Na eventualidade do Banco Central não divulgar ou suspender a divulgação da referida taxa, será utilizada a média de venda praticada por quatro bancos escolhidos pela BM\&F, a seu critério.

A BM\&F poderá ainda, em qualquer caso, arbitrar uma taxa de câmbio se, a seu critério, julgar não serem representativas tanto a cotação divulgada pelo Bacen quanto a média das taxas praticadas pelos bancos por ela consultados.

\section{Condições de liquidação no vencimento}

\section{a) Liquidação financeira}

As posições em aberto após o encerramento do último dia de negociação serão liquidadas financeiramente pela BM\&F, mediante o registro de operação de natureza inversa (compra ou venda) à da posição, na mesma quantidade de contratos, pelo valor de liquidação, calculado pela multiplicação da média aritmética dos últimos cinco dias úteis do Indicador de Preço Disponivel do Boi Gordo ESALQ/BM\&F, do mês de vencimento, pela unidade de negociação, de acordo com a seguinte fómula:

onde:

$V L=$ valor de liquidação por contrato;

$I_{T}$ Indicador de Preço Disponível do Boi Gordo ESALQ/BM\&F, verificado no dia "T", $=$ definido como o índice a vista, expresso em dólares por arroba líquida (US\$/@), apurado pela Escola Superior de Agricultura Luiz de Queiroz-ESALQ e divulgado no Boletim Diário da BM\&F;

D-4 = quarto dia útil anterior à data de vencimento do contrato; $D+0=$ data de vencimento do contrato.

Os resultados financeiros da liquidação serão movimentados no dia útil subseqüente.

b) Liquidação por entrega

- Período de emissão do aviso

Inicia no quinto dia útil anterior à data de vencimento e encerra às 18 horas do dia útil anterior a essa data.

- Data de entrega

A data de pesagem dos animais.

- Local de entrega

Currais localizados no município de Araçatuba (SP), credenciados pela BM\&F.

- Procedimento de entrega

As corretoras de mercadorias, cujos clientes (compradores ou vendedores) estiverem interessados em liquidar suas posições por entrega, emitirão o Aviso de Intenção de Liquidação por Entrega.

Durante o período de entrega, os Avisos de Intenção de Liquidação por Entrega recebidos pela BM\&F até as 9 horas serão divulgados ao mercado no mesmo dia, ficando disponiveis, durante o pregão desse dia, para consulta pelas corretoras. As corretoras de mercadorias, cujos clientes reduzirem suas posições a número inferior ao especificado no Aviso de Intenção de Liquidação por Entrega, devem solicitar seu cancelamento até as 18 horas do dia da operação, para efeito de sua divulgação no pregão do dia seguinte. $\mathrm{Na}$ data de vencimento, a BM\&F fará a conciliação entre as manifestações formais de recebimento e entrega, tomando por base a ordem cronológica de apresentação do Aviso de Intenção de Liquidação por Entrega. Nesse dia, a BM\&F notificará as corretoras cujos clientes deverão liquidar por entrega seus contratos. O saldo remanescente, depois da compatibilização de Avisos de Intenção de Liquidação por Entrega, será liquidado financeiramente, conforme definido no subitem a acima.

A data de entrega, que deverá ser acertada entre as partes para o período compreendido entre 0 segundo e o oitavo dia útil posterior à data de vencimento, será comunicada à 
BM\&F pela corretora do cliente vendedor, mediante a apresentação de Aviso de Entrega, com dois dias úteis de antecedência no mínimo. A BM\&F determinará compulsoriamente, a seu critério, a data de entrega, caso não tenha recebido o correspondente Aviso de Entrega até as 18 horas do sexto dia útil posterior à data de vencimento.

É facultado ao cliente comprador indicar terceiros para quem os bois, objeto deste contrato, devam ser faturados, informando os dados do recebedor para faturamento. 0 comprador substituto fica obrigado, sob a integral responsabilidade do cliente comprador original e até a liquidação final da entrega, a receber os animais. Essa faculdade também se aplica ao cliente vendedor que queira indicar terceiros para realizar a entrega dos animais. Analogamente, o vendedor substituto fica obrigado, sob a integral responsabilidade do cliente vendedor original e até a liquidação final da entrega, a cumprir todas as obrigações e exigências determinadas pelo contrato.

O cliente vendedor, juntamente com o Aviso de Entrega, deve anexar a seguinte documentação:

- declaração de propriedade da mercadoria e de que ela está livre de ônus de qualquer natureza, de emissão do vendedor;

- declaração de conformidade de fixação da data de entrega, emitida conjuntamente com o comprador.

No ato da entrega, o vendedor deverá comprovar o bom estado dos animais, por meio de atestado sanitário exigido por lei.

O não cumprimento de qualquer das obrigações previstas nos procedimentos descritos acarretará multa à parte faltosa, a ser fixada pela BM\&F.

- Procedimentos no local de entrega

A entrega dos animais deverá ser realizada no curral determinado pela BM\&F das 7 às 22 horas do dia anterior à data de pesagem, quando o recinto será fechado, para ser reaberto no dia seguinte. A movimentação física dos animais do local de origem do vendedor aos currais credenciados pela BM\&F em Araçatuba, SP, dentro do Estado de São Paulo, está amparado por Regime Especial de ICMS, concedido pela Secretaria de Fazenda do Estado de São Paulo.

A pesagem e a classificação dos animais serão efetuadas pela BM\&F, no dia posterior à entrada dos animais no curral, dentro do horário estabelecido pela Bolsa, podendo o cliente comprador e o vendedor fiscalizar esses atos. Haverá reidratação dos animais desde o momento da chegada aos currais até o momento da pesagem. Não será oferecida ração aos animais no curral credenciado. A ordem de pesagem será a mesma da ordem de chegada de cada caminhão ao curral, com base no horário médio ponderado de chegada dos animais de cada cliente entregador.

Poderá haver a pesagem de animais no mesmo dia em que deram entrada no curral, se comprador e vendedor estiverem de acordo, devendo as duas partes assinar tal acordo em impresso apropriado, comunicando essa decisão às respectivas corretoras, e estas à BM\&F.

Para a formação do lote de 330 arrobas líquidas, serão considerados $54 \%$ de rendimento do peso bruto, apurado em pesagens individuais, tolerando-se variação de mais ou menos $5 \%$.

Os contratos porventura não cumpridos pagarão multa, a ser estabelecida pela BM\&F, a favor do cliente comprador.

Concluída a pesagem, os animais devem ser retirados do curral, não havendo qualquer responsabilidade do curral, ou da BM\&F, sobre os animais. Caso o cliente comprador não esteja presente para a retirada dos animais, estes serão pesados e arbitrados, permanecendo no curral. Os custos e despesas de permanência dos animais no curral após a pesagem correrão por conta do comprador; nesse caso, o lote será considerado entregue. Durante o período em que os a nimais estiverem sob a responsabilidade do curral, terão a cobertura de apólice de seguro, sendo o valor do prêmio definido no contrato de seguro. As despesas e a responsabilidade pelo transporte dos bois até o curral de entrega são do cliente vendedor. A partir do curral de entrega, as despesas e a 
responsabilidade pelo transporte são do cliente comprador.

- Valor de liquidação

Quando da liquidação por entrega, o valor de liquidação por contrato é calculado multiplicando-se a média aritmética dos últimos cinco dias úteis do Indicador de Preço Disponível do Boi Gordo ESALQ/BM\&F, do mês de vencimento, pelo peso líquido apurado na pesagem dos animais, de acordo com a seguinte fómula:

onde:

VL e IBG ${ }_{T}=$ variáveis definidas no subitem liquidação financeira;

$\mathrm{TC}=$ taxa de câmbio, conforme definida no item $\underline{10}$ à qual também se aplicam as condições especiais nele estipuladas;

PB = peso bruto dos animais entregues, verificado na pesagem realizada no local de entrega.

- Pagamento e recebimento

O pagamento pelo comprador do valor resultante da liquidação por entrega será realizado no dia útil anterior ao da pesagem dos animais, considerando-se 330 arrobas líquidas por contrato. No dia da pesagem, será feito um ajuste no valor de liquidação, com base no peso efetivo apurado no curral de entrega, que será creditado ou debitado no dia útil seguinte, mais o ICMS, se devido, menos o Funrural.

A BM\&F somente pagará à corretora de mercadorias, e esta ao cliente vendedor, quando o comprador, através de impresso apropriado, comprovar que recebeu a mercadoria. Caso o cliente comprador não esteja presente para comprovar que recebeu a mercadoria, 0 representante da BM\&F no curral assinará o impresso apropriado à revelia do comprador, não cabendo, nesse caso, recurso.

- Arbitramento

Todas as entregas serão arbitradas por árbitros escolhidos pela BM\&F, que acompanharão o processo de entrega. A arbitragem realizada dessa forma será final, não

\section{Hedgers} cabendo qualquer recurso contra ela.

Pecuaristas, frigoríficos, indústrias processadoras de carne, comerciantes de carne e fundos de investimento em commodities.

\section{Margem de garantia}

Valor fixo por contrato, devida até o dia útil seguinte ao de abertura da posição, com redução de $20 \%$ para hedgers. A margem de garantia poderá ser alterada a qualquer momento, a critério da Bolsa.

\section{Ativos aceitos como margem}

Dinheiro, ouro, cotas do FIF e, a critério da Bolsa, títulos públicos e privados, cartas de fiança, apólices de seguro, ações e cotas de fundos fechados de investimento em ações.

15. Custos operacionais

\section{- Taxa operacional básica}

Operação normal: $0,30 \%$ do valor da operação; day trade: $0,07 \%$.

A taxa operacional básica, sujeita a valor mínimo estabelecido pela BM\&F, é calculada sobre o preço de ajuste do dia anterior do segundo vencimento em aberto. O valor resultante será convertido para reais pela taxa de câmbio definida no item 10 e verificada no dia útil anterior ao da operação.

- Taxa de liquidação por entrega

Valor divulgado pela BM\&F, devido na data de pagamento/recebimento do valor de liquidação.

- Taxas da Bolsa (emolumentos e fundos)

$6,32 \%$ da taxa operacional básica.

- Taxa de registro

Valor fixo divulgado pela BM\&F.

Os custos operacionais, à exceção da taxa de liquidação por entrega, são devidos no dia útil seguinte ao de realização da operação no pregão.

Os sócios efetivos pagarão no máximo $75 \%$ da taxa operacional básica e da taxa de liquidação 
por entrega e $75 \%$ dos demais custos operacionais (taxas de registro e da Bolsa).

Os investidores institucionais pagarão $75 \%$ das taxas de registro e da Bolsa.

16. Normas complementares

Fazem parte integrante deste contrato a legislação em vigor e as nomas e os procedimentos da BM\&F, definidos em seus Estatutos Sociais, Regulamento de Operações e ofícios circulares, bem como no Protocolo de Intenções fimado entre as bolsas de valores, de mercadorias e de mercados de liquidação futura, de $\mathbf{2 5 . 5 . 8 8}$, observadas, adicionalmente, as regras específicas do Banco Central do Brasil.

ÚLTIMA ATUALIZAÇÃO: OFÍCIO CIRCULAR 092/97-SG, DE 18.7.97 


\section{APÊNDICE 2}

Contrato futuro cambial de soja em grão a granel 


\section{Especificações do Contrato Futuro Cambial de Soja em Grão a Granel}

\section{Objeto de negociação}

Soja em grão a granel, de tipo exportação, conforme padrão CONCEX (Resolução CONCEX 169, de 8.3.89), com até $14 \%$ de umidade; base de $1 \%$, não ultrapassando o máximo de $2 \%$ de impurezas; máximo de $8 \%$ de avariados, estes com até $5 \%$ de ardidos; máximo de $10 \%$ de grãos verdes e de $30 \%$ de grãos quebrados, observada a unidade de negociação definida no item $\underline{5}$, cujo valor será expresso em pontos, na forma indicada no item $\underline{2}$.

\section{Cotação}

Pontos por 60 quilos líquidos de soja em grão, a granel, com duas casas decimais, sendo cada ponto equivalente à taxa de câmbio (TC) de real por dólar dos Estados Unidos da América, tal como definida no item 10.

3. Variação mínima de apregoação

0,01 ponto (equivalente a US\$0,01) por 60 quilos líquidos.

4. Oscilação máxima diária

O limite de oscilação é fixado pela BM\&F.

A BM\&F poderá, a qualquer momento, alterar os limites de oscilação, bem como sua aplicação aos diversos vencimentos.

5. Unidade de negociação

27 toneladas métricas, correspondentes a 450 unidades de 60 quilos líquidos cada, de soja em grão a granel.

6. Meses de vencimento

Fevereiro, março, maio, julho, setembro e novembro.

7. Número de vencimentos em aberto

No máximo dez.

8. Data de vencimento e último dia de negociação

Último dia útil do mês de vencimento.

9. Day Trade

São admitidas operações de compra e venda para liquidação diária (day trade), desde que realizadas no mesmo pregão, pelo mesmo cliente (ou operador especial), intermediadas pela mesma corretora de mercadorias e registradas pelo mesmo membro de compensação. Os resultados auferidos nessas operações são movimentados financeiramente no dia útil seguinte ao de sua realização. O valor em dólares será convertido em reais pela taxa de câmbio (TC) definida no item 10.

10. Ajuste diário

As posições em aberto ao final de cada pregão serão ajustadas com base no preço de ajuste do dia, estabelecido no call de fechamento, conforme regras da Bolsa, com movimentação financeira no dia útil subseqüente.

O ajuste diário será calculado de acordo com as seguintes fórmulas:

a) ajuste das posições realizadas no dia

$A D=\left(P A^{t}-P O\right) \times T C \times 450 \times n$

b) ajuste das posições realizadas no dia anterior

$A D=\left(P A^{t}-P A^{t-1}\right) \times T C \times 450 \times n$

onde:

$A D=$ valor do ajuste diário;

$\mathrm{PA}^{\mathrm{t}}=$ preço de ajuste do dia, expresso em dólares dos Estados Unidos da América por 60 quilos líquidos;

$\mathrm{PO}=$ preço da operação, expresso em dólares dos Estados Unidos da América por 60 quilos líquidos;

TC = taxa de câmbio de real por dólar dos Estados Unidos, para entrega pronta, verificada no dia, contratada nos termos da Resolução 1690/90, do Conselho Monetário Nacional- 
CMN, definida como a taxa média de venda apurada pelo Bacen, segundo critérios por ele definidos, e divulgada em D+1 pelo Sisbacen, transação PTAX800, opção "5-L" (cotação de fechamento), e que será utilizada com até quatro casas decimais;

$\mathrm{n}=$ número de contratos;

$\mathrm{PA}^{\mathrm{t}-1}=$ preço de ajuste do dia anterior.

O valor do ajuste diário, se positivo, será creditado ao comprador e debitado ao vendedor.

Caso o valor seja negativo, será debitado a o comprador e creditado ao vendedor.

- Condições especiais

$\mathrm{Na}$ eventualidade de o Banco Central não divulgar a referida taxa, será utilizada a média de venda praticada por quatro bancos escolhidos pela BM\&F, a seu critério.

A BM\&F poderá ainda, em qualquer caso, arbitrar uma taxa de câmbio se, a seu critério, julgar não serem representativas tanto a cotação divulgada pelo Bacen quanto a média das taxas praticadas pelos bancos por ela consultados.

\section{Pontos de entrega}

Rio Grande (RS) e Paranaguá (PR).

12. Condições de liquidação

Exceto por acordo expresso entre as partes interessadas, mediante procedimentos próprios, fixados pela BM\&F no Anexo ao presente contrato, item A (Procedimentos de Liquidação Mediante Entrega/Recebimento de Soja), em nenhuma outra hipótese poderá ocorrer liquidação através da entrega da mercadoria objeto deste contrato.

Todos os contratos ainda em aberto ao se encerrar o pregão da data de vencimento serão liquidados financeiramente no dia útil subseqüente, pelo valor correspondente ao Preço Nacional da Soja verificado na data de vencimento.

\section{Hedgers}

Produtores, cooperativas, cerealistas, indústrias de farelo e de óleo de soja, importadores e exportadores de soja, bem como fornecedores de insumos e equipamentos agrícolas ligados ao mercado de soja.

14. Margem de garantia

Valor fixo por contrato, devida até o dia útil seguinte ao de abertura de posição, com redução de $20 \%$ para hedgers. A margem de garantia poderá ser alterada a qualquer momento, a critério da Bolsa.

15. Ativos aceitos como margem

Dinheiro, ouro , cotas do FIF e, a critério da Bolsa, títulos públicos e privados, cartas de fiança, apólices de seguro, ações, cotas de fundos fechados de investimentos em ações, certificados de custódia e warrants endossáveis, de emissão de armazém credenciado pela BM\&F.

16. Custos operacionais

\section{- Taxa operacional básica}

Operação normal: 0,3\%; day trade: $0,07 \%$.

A taxa operacional básica, sujeita a valor mínimo estabelecido pela Bolsa, é calculada sobre o preço de ajuste do dia anterior do segundo vencimento em aberto. O valor resultante será convertido para reais pela taxa de câmbio definida no item 10 e verificada no dia útil anterior ao da operação.

- Taxa de liquidação por entrega/recebimento de soja Valor divulgado pela BM\&F.

- Taxas da Bolsa (emolumentos e contribuição para o Fundo de Garantia)

$6,32 \%$ da taxa operacional básica e da taxa de liquidação por entrega, quando houver.

- Taxa de registro

Valor fixo divulgado pela BM\&F.

Os custos operacionais, à exceção da taxa de liquidação por entrega, são devidos no dia útil seguinte ao dia da realização da operação no pregão.

Os sócios efetivos pagarão no máximo $75 \%$ da taxa operacional básica e da taxa de liquidação por entrega e $75 \%$ dos demais custos operacionais (taxas de registro e da Bolsa).

Os investidores institucionais pagarão $75 \%$ das taxas de registro e da Bolsa. 


\section{Preço disponivel: Preço Nacional da Soja}

A Bolsa informará diariamente o preço FIPE da soja no mercado disponível, a ser designado Preço Nacional da Soja. Esse preço será calculado pela Fundação Instituto de Pesquisas Econômicas-FIPE, da Universidade de São Paulo, em reais, sendo expresso, para efeito de divulgação no Boletim Diário da BM\&F, tanto em reais quanto em dólares dos Estados Unidos da América, sendo utilizada para conversão, tão-somente nesse caso, uma prévia da taxa de venda do dólar comercial para o dia, obtida junto ao mercado pela BM\&F, a seu critério. O citado preço, estabelecido por média geométrica, será diariamente determinado pela FIPE, através de dados levantados em pontos selecionados de coleta, nas principais áreas de produção, sendo os respectivos valores numéricos, por unidade de 60 quilos líquidos, devidamente ponderados segundo critérios também estipulados pela FIPE. As cotações objeto de negociação deste contrato referir-se-ão sempre às expectativas quanto aos valores futuros do Preço Nacional da Soja, considerada a unidade de negociação referida no item $\underline{2}$.

- Levantamento diário do Preço Nacional da Soja

Estando a FIPE, por motivos alheios a sua vontade, impossibilitada de efetuar o necessário levantamento diário do Preço Nacional da Soja, a BM\&F adotará os procedimentos mais adequados na circunstância para obter os dados para elaboração do Preço Nacional da Soja.

\section{Normas complementares}

Fazem parte integrante deste contrato o Anexo único, a legislação em vigor e as normas e os procedimentos da BM\&F, definidos em seus Estatutos Sociais, Regulamento de Operações e ofícios circulares, bem como no Protocolo de Intenções firmado entre as bolsas de valores, de mercadorias e de mercado de liquidação futura, de $\mathbf{2 5 . 5 . 8 8}$, obsenvadas, adicionalmente, as regras específicas do Banco Central do Brasil.

\section{Anexo}

\section{A) Procedimentos de Liquidação Mediante Entrega/Recebimento de Soja}

\section{Processamento dos Avisos de Intenção de Liquidação mediante entrega da soja}

1. As corretoras de mercadorias, cujos clientes (vendedores) desejarem liquidar suas posições mediante entrega de soja e formalizarem tal interesse, emitirão o Aviso de Intenção de Liquidação por Entrega a partir do quinto dia útil anterior ao último dia de negociação, até esta mesma data_(inclusive). Os avisos recebidos pela BM\&F até às 10 horas serão divulgados no pregão do dia.

2. Cada Aviso, obrigatoriamente acompanhado dos anexos indicados no item 2.2 abaixo, especificará, necessariamente: (a) o ponto de entrega (município de Rio Grande e Paranaguá), (b) o número de contratos e a respectiva quantidade, cuja liquidação por entrega é intencionada, (c) o prêmio mínimo pretendido, acima do preço de ajuste do dia do arremate, sobre o qual será calculado o preço contratual de entrega/recebimento físico e (d) o nome do armazém/silo onde a mercadoria se encontra integralmente depositada em nome do vendedor. O nome do armazém/silo depositário deverá necessariamente constar da lista de armazéns/silos aprovados pela BM\&F, para efeito dos presentes procedimentos.

3. No final de cada dia, imediatamente após o call de fechamento, serão leiloados os Avisos de Entrega, na forma do item $\underline{B}$ abaixo, por ordem cronológica de recebimento.

4. Os avisos não arrematados serão cancelados, devendo ser renovados no dia útil seguinte, se de interesse do vendedor.

5. As posições vendidas, relativas a avisos não arrematados no último leilão, serão liquidadas financeiramente, tal como estipulado no segundo parágrafo do item $\underline{12}$ do contrato.

2. Efetivação das entregas/recebimentos

1. As entregas/recebimentos serão efetuadas no dia útil seguinte à data de arremate do respectivo aviso.

2. Cada aviso deverá, necessariamente, ser acompanhado dos seguintes documentos: 
- Recibo de Depósito e Declaração de Propriedade de Mercadoria, emitido pelo armazém/silo depositário, contendo indicação do nome do proprietário e da quantidade de soja em grão depositada. Nesse documento, deverá obrigatoriamente constar que a mercadoria é de exclusiva propriedade da pessoa jurídica ou física em cujo nome está registrada, estando livre de débitos e de ônus de qualquer espécie, inclusive pendências de natureza fiscal.

- Certificado de Classificação, emitido por órgão de classificação de escolha do proprietário (vendedor) da soja dentre os nomes de órgãos de classificação indicados pela BM\&F. Esse certificado será emitido na ocasião do recebimento da soja no armazém/silo depositário, em data não superior a 30 dias corridos, em antecedência ao dia de apresentação do aviso, e terá caráter final e irrecorrivel, devendo atestar que a mercadoria a que se refere está em estrita conformidade com as especificações constantes do item 1 do Contrato Futuro Cambial de Soja em Grão a Granel. Seu original, devidamente numerado, será enviado pelo órgão de classificação diretamente à BM\&F, que, após registrá-lo, o colocará à disposição da corretora do vendedor (proprietário).

- Ordem de Entrega Provisória, nominal à BM\&F, emitida pelo armazém/silo depositário.

\section{Valor de liquidação}

Quando da liquidação por entrega/recebimento, o valor de liquidação por contrato será calculado adicionando-se o prêmio adjudicado em leilão, expresso em pontos/60kg líquidos, ao preço de ajuste da data do arremate do aviso, também expresso em pontos/60kg líquidos. O valor dessa soma será multiplicado pela taxa de câmbio (TC) de real por dólar dos Estados Unidos da América, definida no item 10 do Contrato Futuro de Soja em Grão a Granel e divulgada no dia útil seguinte à referida data de arremate. $O$ produto resultante será, por sua vez, multiplicado por 450 (quantidade contratual, expressa em número de unidades de $60 \mathrm{~kg}$ líquidos), deduzindo-se ainda eventual desconto por excesso de impurezas, acima da tolerância de $1 \%$, até o máximo admitido de $2 \%$, obedecida a proporção de $1: 1$.

O valor de liquidação por contrato poderá também ser obtido através da seguinte fómula:

$$
V L=[(C+P) \times T C] \times 450]-f(i)
$$

onde:

$\mathrm{VL}=$ valor de liquidação por contrato;

$C=$ preço de ajuste do pregão da data (D) de arremate do Aviso;

$P=$ prêmio adjudicado;

TC taxa de câmbio definida no item $\underline{10}$ do Contrato Futuro de Soja em Grão a Granel e

$=$ divulgada em $\mathrm{D}+1$;

$f(i)=$ eventual desconto percentual de valor por possivel excesso de impurezas acima da tolerância contratual de $1 \%$, até o máximo admitido de $2 \%$, observada a proporção de 1:1.

O valor da liquidação é livre de impostos. Nas operações em que houver incidência de ICMS, este será acrescido ao valor de liquidação, compondo o preço de faturamento. A contribuição de seguridade (INSS) estará incluida no preço de faturamento, integrando, portanto, o preço-base da mercadoria, e será sempre recolhida conforme o disposto na Lei 8212, de 24.7.91, e alterações posteriores.Nas operações em que o cliente comprador, nos termos do artigo 30 da citada lei, for obrigado ao recolhimento da contribuição de seguridade, ou sub-rogado da obrigação de recolhê-la, a BM\&F descontará do preço devido ao cliente vendedor, por ocasião da liquidação, o valor equivalente à contribuição, o qual será recolhido pelo cliente comprador. 0 recolhimento do PIS e da Cofins, quando devidos, será feito diretamente pelo cliente vendedor, nas formas e nos prazos estabelecidos pela legislação em vigor, integrando, portanto, o preçobase do objeto deste contrato. Aplicam-se as condições especiais, definidas no item 10 do Contrato Futuro Cambial de Soja em Grão a Granel, à variável TC (taxa de câmbio).

4. Custos operacionais referentes à entrega/recebimento de soja

O custo de emissão do Certificado de Classificação será de responsabilidade do vendedor, independentemente do fato de a entrega/recebimento da soja vir a se concretizar ou não. Efetivando-se a entrega/recebimento da soja, qualquer eventual quebra de estoque será de responsabilidade do vendedor. Os custos de armazenagem serão de responsabilidade do vendedor até, pelo menos, a data de apresentação do respectivo aviso. Havendo tais custos sido 
pagos pelo vendedor por quinzena e expirando-se a mesma em data posterior à citada data de apresentação do aviso, as despesas de armazenagem somente correrão por conta do comprador após o término da mencionada quinzena.

5. Pagamento, recebimento e transferência de propriedade da mercadoria

A compensação financeira do valor resultante da liquidação por entrega/recebimento será debitada ao comprador no dia útil subsequente à data de arremate do aviso. Na mesma data, a BM\&F informará diretamente ao armazém/silo depositário os dados do adquirente da soja, para efeito de transferência de propriedade da mercadoria e de emissão da necessária nota-fiscal de venda, de parte do vendedor. Ainda obrigatoriamente na mesma data, o amazém/silo depositário efetuará a transferência da propriedade da mercadoria para o nome do comprador, comunicando imediatamente tal fato à BM\&F, por telex ou outro meio aprovado pela Bolsa. Ao receber tal comunicação, a BM\&F creditará em favor do vendedor o valor devido de liquidação.

\section{B) Procedimentos para a realização de leilões de Avisos}

1. A relação dos avisos recebidos até às 10 horas será divulgada pela BM\&F, durante o pregão, dela constando, com respeito a cada aviso:

a) o respectivo número de ordem, dada a sequência cronológica de recebimento;

b) o número de contratos referidos e a respectiva quantidade;

c) o ponto de entrega (município);

d) o nome do armazém/silo depositário, onde se encontra a mercadoria a ser entregue, e

e) o prêmio mínimo pretendido, na forma do item (A) 1.2 deste Anexo.

2. Os leilões de avisos serão realizados imediatamente após o témino do call de fechamento do Contrato Futuro Cambial de Soja em Grão a Granel.

3. Os avisos serão apregoados por ordem cronológica de recebimento pela BM\&F.

4. Somente poderão participar dos leilões de avisos corretoras cujos clientes sejam detentores de posições compradas, obsenvado o mês de vencimento a que se referem os avisos. A não observância dessa regra implicará na responsabilidade da corretora, a ser-lhe imputada pela Bolsa, por todos os prejuizos decorrentes causados ao mercado.

5. O Aviso não arrematado perderá a validade.

6. À corretora responsável pelo lance ganhador será atribuído o respectivo Aviso leiloado, sendo a correspondente posição liquidada por entrega/recebimento, conforme o item A deste Anexo.

\section{C) Procedimentos para a realização de operações de trocas de futuros (ex pit)}

Serão permitidas operações de troca de posições futuras (ex pit), exclusivamente para viabilizar operações entre hedgers, de contratos de compra e venda de soja no mercado físico, com cláusula de preço a fixar. Para registro dessas operações, serão observadas as seguintes regras:

1. As corretoras representantes dos clientes titulares das posições em aberto, observadas as premissas acima citadas, deverão solicitar à BM\&F, em pregão, o registro da transação, preenchendo o cartão de negociação.

2. Não serão autorizadas operações ex pit a preços fora de mercado, considerando-se preço de mercado:

a) qualquer preço entre o mínimo e o máximo do dia;

b) o preço de ajuste do dia anterior, caso no momento do registro da transação ainda não tenha ocorrido negócio para o vencimento em apreço.

3. Somente serão permitidas operações ex pit até o último dia útil do mês anterior ao mês de vencimento a que se referirem tais operações. 


\section{APÊNDICE 3}

Esquema representando o processo de resolução de uma normal tetra variável pela "aproximação de Cholesky" 
Passos a serem seguidos:

1ํ) Determinar a matriz de correlação entre as variáveis:

$\sum=\left[\begin{array}{ll}\sigma_{11} & \sigma_{12} \\ \sigma_{21} & \sigma_{22}\end{array}\right]$

2-) Aproximação de Cholesky:

$\sum=\mathrm{AA}^{\prime}$

$\mathrm{A}=\left[\begin{array}{ll}a_{11} & a_{12} \\ a_{21} & a_{22}\end{array}\right]$

onde:

$\mathrm{a}_{\mathrm{ij}}=0, \operatorname{para} \mathrm{j}>\mathrm{i}$;

$a_{11}=\sqrt{\sigma_{11}} ;$

$\mathrm{a}_{\mathrm{il}}=\frac{\sigma_{i 1}}{\sqrt{\sigma_{11}}}, \operatorname{para} \mathrm{i}>1$;

$\mathrm{a}_{\mathrm{jj}}=\left(\sigma_{j j}-\sum_{k=1}^{j-1} a_{j k}^{2}\right)$

$\mathrm{a}_{\mathrm{ij}}=\left(\sigma_{i j}-\sum_{k=1}^{j-1} \frac{a_{i k} a_{j k}}{a_{i j}}\right)$.

Portanto:

$$
A=\left[\begin{array}{cc}
\sqrt{\sigma_{11}} & 0 \\
\frac{\sigma_{21}}{\sqrt{\sigma_{11}}} & \sqrt{\sigma_{22}-\frac{\sigma_{21}^{2}}{\sigma_{11}^{2}}}
\end{array}\right] .
$$


3) Multiplicar a matriz A pela matriz com as variáveis (preços - série de dados da análise). Esta etapa tem como objetivo eliminar a correlação entre os preços de cada localização (a correlação torna-se inerente `a série).

4 $^{\mathbf{0}}$ ) Calcular as probabilidades das localizações serem as mais baratas, simultaneamente.

Na prática, procedeu-se da seguinte maneira:

a) a matriz de correlação foi montada utilizando-se da planilha eletrônica Excel, onde foram considerados todos os dados da série;

b) essa matriz foi inserida em um programa desenvolvido no SAS, obtendo-se, assim, as probabilidades desejadas.

\section{Programa desenvolvido:}

Proc IML;

*/ Os R's são as matrizes de correlações entre os preços que comporão o indicador */

$\mathrm{R} 1=\{\} ;$

$\mathrm{R} 2=\{\}$;

$\mathrm{R} 3=\{\}$;

$\mathrm{R} 4=\{\}$;

*/ Os A's são as matrizes obtidas a partir da decomposição de Cholesky */

$\mathrm{A} 1=\operatorname{root}(\mathrm{R} 1)$

$\mathrm{A} 2=\operatorname{root}(\mathrm{R} 2)$;

$\mathrm{A} 3=\operatorname{root}(\mathrm{R} 3)$;

$\mathrm{A} 4=\operatorname{root}(\mathrm{R} 4)$;

*/ O P é a matriz dos preços das regiões que irão compor o indicador */

$\mathrm{P}=\{\}$; 
$\mathrm{Y} 1=\mathrm{A}^{\prime} * \mathrm{P}^{\prime}$

$\mathrm{Y} 2=\mathrm{A} 2{ }^{\prime} * \mathrm{P}^{\prime}$;

$\mathrm{Y} 3=\mathrm{A} 3^{\prime} * \mathrm{P}^{\prime}$

$\mathrm{Y} 4=\mathrm{A} 4{ }^{\prime} * \mathrm{P}^{\prime}$;

$\mathrm{U} 1 \mathrm{~L}=\mathrm{Y} 11^{\prime}$;

$\mathrm{U} 2 \mathrm{~L}=\mathrm{Y} 2$;

$\mathrm{U} 3 \mathrm{~L}=\mathrm{Y}^{\prime}$;

$\mathrm{U} 4 \mathrm{~L}=\mathrm{Y} 4^{\prime}$;

*/ Definição das dimensões das matrizes Z's */

$Z 1=$ shape( );

$\mathrm{Z2}=$ shape ( );

$\mathrm{Z3}=$ shape ( );

Z4=shape( );

*/ Calcula as probabilidades de cada localização ser a mais barata */

do $\mathrm{i}=1$ to tamanho da matriz;

$\mathrm{Z1}[\mathrm{i}]=$-probnorm(U1L[i,1])*probnorm(U1L[i,2])*probnorm(U1L[i,3])* probnorm(U1L[i,4]);

Z2[i]=probnorm(U2L[i,1])*probnorm(U2L[i,2])*probnorm(U2L[i,3])* probnorm(U2L[i,4]);

Z3[i]=probnorm(U3L[i,1])*probnorm(U3L[i,2])*probnorm(U3L[i,3])* probnorm(U3L[i,4]);

$\mathrm{Z} 4[\mathrm{i}]=$ probnorm $(\mathrm{U} 4 \mathrm{~L}[\mathrm{i}, 1])$ *probnorm(U4L[i,2])*probnorm(U4L[i,3])* probnorm(U4L[i,4]);

end;

*/ Imprimir as probabilidade calculadas */

print Z1 Z2 Z3 Z4;

quit; 


\section{APÊNDICE 4}

Processo de construção de um indicador baseado na probabilidade das localizações participantes possuírem o menor preço 
Procedimento para o cálculo do indicador:

$P C L=e^{r T}\left[P_{i t} W_{1 t}+P_{2 t} W_{2 t}+P_{3 t} W_{3 t}+P_{4 t} W_{4 t}\right] ;$

sendo que os componentes do preço comum de liquidação foram definidos no texto.

$I_{t}^{\mathrm{EMB}}=\mathrm{e}^{\mathrm{rT}}\left[\mathrm{P}_{1 \mathrm{t}} \widehat{\mathrm{W}}_{1}+\mathrm{P}_{2 \mathrm{t}} \widehat{\mathrm{W}}_{2}+\mathrm{P}_{3 \mathrm{t}} \widehat{\mathrm{W}}_{3}+\mathrm{P}_{4 \mathrm{t}} \widehat{\mathrm{W}}_{4}\right]$

sendo: $\widehat{W}_{i}=\frac{1}{\tau} \sum_{\mathrm{k}=0}^{\tau} \mathrm{W}_{\mathrm{ik}}, \tau=30$ dias

\begin{tabular}{cccc|cccc|cccc}
\hline $\mathrm{P}_{\mathrm{AR}}$ & $\mathrm{P}_{\mathrm{PP}}$ & $\mathrm{P}_{\mathrm{SRRP}}$ & $\mathrm{P}_{\mathrm{BA}}$ & $\mathrm{W}_{\mathrm{AR}}$ & $\mathrm{W}_{\mathrm{PP}}$ & $\mathrm{W}_{\mathrm{S} J R P}$ & $\mathrm{~W}_{\mathrm{BA}}$ & $\hat{\mathrm{W}}_{\mathrm{AR}}$ & $\hat{\mathrm{W}}_{\mathrm{PP}}$ & $\hat{\mathrm{W}}_{\mathrm{S} R \mathrm{PP}}$ & $\hat{\mathrm{W}}_{\mathrm{BA}}$ \\
\hline 20,12 & 18,19 & 17,09 & 21,00 & 0,8712 & 0,9234 & 0,9657 & 0,8234 & - & - & - & - \\
$\cdot$ & $\cdot$ & $\cdot$ & $\cdot$ & $\cdot$ & $\cdot$ & $\cdot$ & $\cdot$ & $\cdot$ & $\cdot$ & $\cdot$ & $\cdot$ \\
$\cdot$ & $\cdot$ & $\cdot$ & $\cdot$ & $\cdot$ & $\cdot$ & $\cdot$ & $\cdot$ & $\cdot$ & $\cdot$ & $\cdot$ & $\cdot$ \\
$\cdot$ & $\cdot$ & $\cdot$ & $\cdot$ & $\cdot$ & $\cdot$ & $\cdot$ & $\cdot$ & $\cdot$ & $\cdot$ & $\cdot$ & $\cdot$ \\
20,46 & 19,07 & 18,98 & 21,76 & 0,8612 & 0,9056 & 0,9587 & 0,8178 & - & - & - & - \\
\hline 20,54 & 19,12 & 18,67 & 21,23 & 0,8725 & 0,9101 & 0,9612 & 0,8267 & 0,8662 & 0,9145 & 0,9622 & 0,8206 \\
\hline
\end{tabular}

- $\mathrm{P}_{\mathrm{AR}}, \mathrm{P}_{\mathrm{PP}}, \mathrm{P}_{\mathrm{SJRP}}, \mathrm{P}_{\mathrm{BA}}$ : Preços físicos das regiões de Araçatuba, Presidente Prudente, São José do Rio Preto e Bauru, respectivamente.

- $\mathrm{W}_{\mathrm{AR}}, \mathrm{W}_{\mathrm{PP}}, \mathrm{W}_{\mathrm{SJRP}}$ e $\mathrm{W}_{\mathrm{BA}}$ : probabilidades de que as regiões citadas serão as mais baratas, levando-se em conta os preços diários e as suas correlações ao longo da série.

- $\hat{\mathrm{W}}_{\mathrm{AR}}, \hat{\mathrm{W}}_{\mathrm{PP}}, \hat{\mathrm{W}}_{\mathrm{SIRP}}$ e $\hat{\mathrm{W}}_{\mathrm{BA}}$ : são as probabilidades definidas acima ponderadas ao longo de 30 dias.

As probabilidades ponderadas, são então substituídas na fórmula do $\mathbf{I}^{\text {EMB }}$ onde calcula-se $\mathrm{o}$ indicador que, posteriormente, será analisado, 
comparativamente às demais especificações, com relação à sua eficiência e a sua variabilidade. 


\section{APÊNDICE 5}

Exemplificação da determinação de prêmios/descontos com a utilização de uma média móvel, para o estreitamento entre as diferenças de preços das regiões participantes do indicador 
Os prêmios/descontos são determinados da seguinte maneira:

$\mathrm{P}_{\text {it }}=\mathrm{P}_{\mathrm{it}}+\delta_{\mathrm{it}}$

$\delta_{i t}=\frac{1}{t^{*}} \sum_{j=1}^{*}\left(P_{k, t-j}-P_{i, t-j}\right) \quad \mathrm{i}=1,2, \ldots, \mathrm{I}$.

onde: $\delta_{\text {it }}$ é o ajustamento da média móvel; $P_{\mathrm{K}, \mathrm{t}-\mathrm{j}}$ é o último preço na localização Araçatuba; $\quad \mathrm{P}_{\mathrm{i}, \mathrm{t}-\mathrm{j}}$ é o último preço nas demais localizações; $\mathrm{e}, \mathrm{t}^{*}$ é período que se calcula a média móvel (5 dias).

No caso específico da commodity boi gordo, a utilização dos prêmios/descontos teve como objetivo reduzir as diferenças de preços, entre as regiões que compõem o indicador, trazendo os preços das outras regiões para mais próximos dos preços da região de Araçatuba. Por exemplo, dada a série de preços, tem-se:

\begin{tabular}{cccc}
\hline $\mathrm{P}_{\mathrm{AR}}$ & $\mathrm{P}_{\mathrm{PP}}$ & $\mathrm{P}_{\mathrm{SRP}}$ & $\mathrm{P}_{\mathrm{BA}}$ \\
\hline 20,21 & 19,21 & 18,34 & 22,90 \\
21,23 & 20,23 & 20,87 & 21,08 \\
20,34 & 21,34 & 20,18 & 20,23 \\
23,01 & 22,01 & 21,09 & 21,34 \\
22,21 & 21,71 & 20,12 & 23,45 \\
\hline 21,50 & $20,50+(0,50)=21,00$ & $20,54+\left(\delta_{\mathrm{SRRP}}\right)$ & $22,56+\left(\delta_{\mathrm{BA}}\right)$ \\
\hline
\end{tabular}

$\delta_{\mathrm{PP}}=1 / 5[(20,21-19,21)+(21,23-20,23)+(20,34-21,34)+(23,01-22,01)+(22,21-21,71)]$

$\delta_{\mathrm{PP}}=1 / 5(2,50)$

$\delta_{\mathrm{PP}}=0,50$

Após feito este ajustamento, têm-se novos preços regionais que irão passar pelo processo detalhado a partir do item 4.1 até chegar à construção de um novo indicador que, será submetido a uma análise de eficiência e de variabilidade, 
sendo que os resultados serão comparados aos obtidos a partir das outras especificações. 